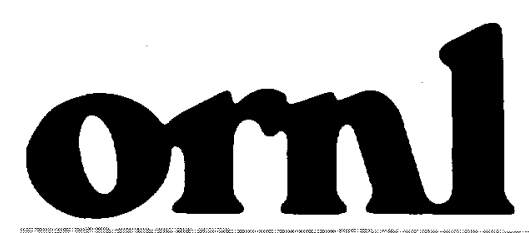

WII)

OAK RIDGE

NATIONAL

LABORATORY

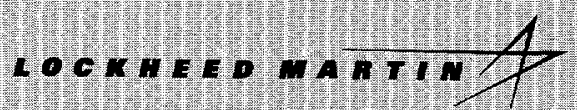
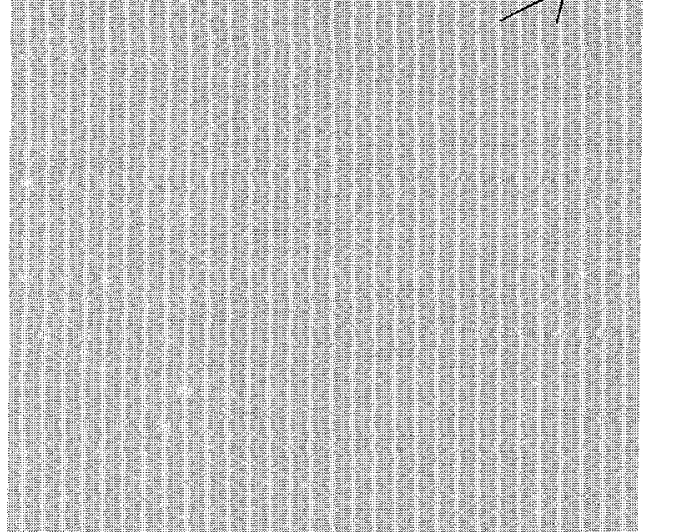

(1)

隹

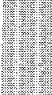

W)

\author{
RECEIVED \\ Energy Division OS TI
}

\section{Method For Developing Descriptions of Hard-To-Price Products: Results of the Telecommunications Products Study}

Bruce Tonn

Fred Conrad ${ }^{\dagger}$

${ }^{{ }^{\top} \text { Bureau of Labor Statistics }}$

May 1999 



\section{DISCLAIMER}

This report was prepared as an account of work sponsored by an agency of the United States Government. Neither the United States Government nor any agency thereof, nor any of their employees, make any warranty, express or implied, or assumes any legal liability or responsibility for the accuracy, completeness, or usefulness of any information, apparatus, product, or process disclosed, or represents that its use would not infringe privately owned rights. Reference herein to any specific commercial product, process, or service by trade name, trademark, manufacturer, or otherwise does not necessarily constitute or imply its endorsement, recommendation, or favoring by the United States Government or any agency thereof. The views and opinions of authors expressed herein do not necessarily state or reflect those of the United States Government or any agency thereof. 


\section{DISCLAIMER}

Portions of this document may be illegible in electronic image products. Images are produced from the best available original document. 


\title{
METHOD FOR DEVELOPING DESCRIPTIONS OF HARD-TO-PRICE PRODUCTS: RESULTS OF THE TELECOMMUNICATIONS PRODUCTS STUDY
}

\author{
Bruce Tonn \\ Oak Ridge National Laboratory \\ Fred Conrad \\ Bureau of Labor Statistics
}

May 1999

\begin{abstract}
TThis submitted manos cript has been authored \%y 2 contractor of the 0 , s. sovernment under contract No DE 4 C05 $960 R 22464$ Accordingly. the US Governmen retains a nonexclusive, roy alty free licenseto pubis th or reproduce the pubits hed form ol this contribution or allow

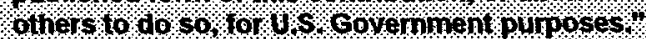

\author{
Prepared for \\ Department of Labor \\ Bureau of Labor Statistics \\ Prepared by \\ Oak Ridge National Laboratory \\ Oak Ridge, Tennessee 37831 \\ managed by \\ LOCKHEED MARTIN ENERGY RESEARCH CORP. \\ for the \\ U.S. DEPARTMENT OF ENERGY \\ under Contract No. DE-AC05-96OR22464
}



TABLE OF CONTENTS

EXECUTIVE SUMMARY $\ldots \ldots \ldots \ldots \ldots \ldots \ldots \ldots \ldots \ldots \ldots \ldots \ldots \ldots$

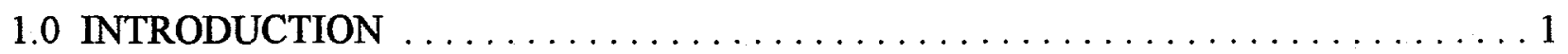

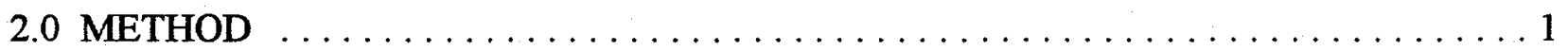

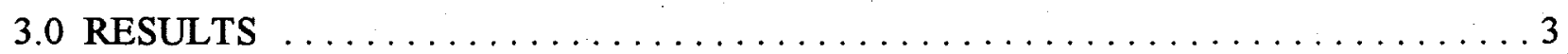

4.0 OBSERVATIONS AND CONCLUSIONS $\ldots \ldots \ldots \ldots \ldots \ldots \ldots \ldots \ldots \ldots$

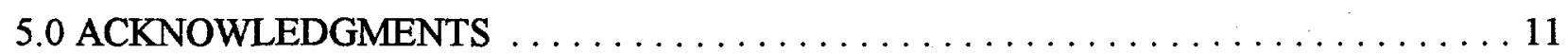

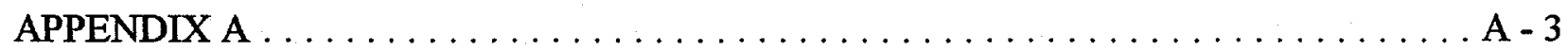

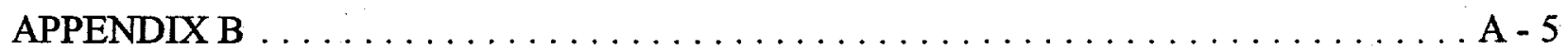

APPENDIX C . . . . . . . . . . . . . . . . . 15

APPENDIX D . . . . . . . . . . . . . . . . . . . . . 20

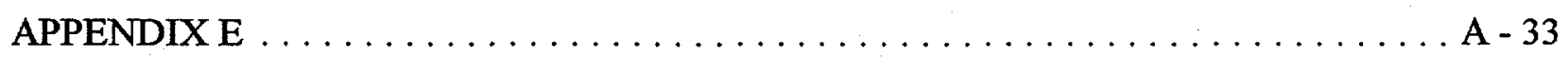

APPENDIX F . . . . . . . . . . . . . . . . . . . . . . 36

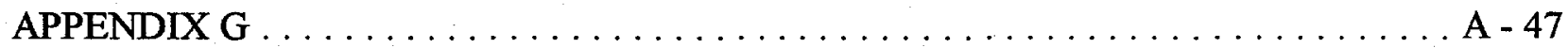





\section{EXECUTIVE SUMMARY}

This report presents the results of a study to test a new method for developing descriptions of hard-toprice products. The Bureau of Labor Statistics (BLS) is responsible for collecting data to estimate price indices such as the Consumers Price Index (CPI). BLS accomplishes this task by sending field staff to places of business to price actual products. The field staff are given product checklists to help them determine whether products found today are comparable to products priced the previous month. Prices for non-comparable products are not included in the current month's price index calculations. A serious problem facing BLS is developing product checklists for dynamic product areas, new industries, and the service sector. It is difficult to keep checklists up-to-date and quite often simply to develop checklists for service industry products. Some people estimate that upwards of $50 \%$ of U.S. economic activity is not accounted for in the CPI.

The objective of this project was to test a method for helping BLS staff build new product checklists quickly and efficiently. The domain of study was the telecommunications industry. The approach is to test a method developed by Oak Ridge National Laboratory (ORNL) which is based on behavioral science and knowledge engineering principles. The method has ten steps, which include: developing a sample of domain experts, asking experts to list products in the domain, culling the list of products to a manageable number, asking experts to group the remaining products, identifying product clusters using multi-dimensional scaling and cluster analysis techniques, asking experts to compare pairs of products within clusters, and finally developing checklists with the comparison data.

The method performed as expected. Several prototype checklists for products in the telecommunications domain were developed, including checklists for paging services, digital cell phones, web browsers, routers, and LAN modems. It was particularly difficult, however, to find experts to participate in the project. Attending a professional meeting and contacting experts from the conference's mailing list proved to be the best approach for this domain.

The method has performed well in two domains, the telecommunications industry, as demonstrated in this project, and the PC software industry, as demonstrated in a previous project. It is recommended that the method be further tested in additional service industries, such as nursing homes. Also, further 
attention needs to be devoted to proceduralizing the method to improve its cost and time efficiency. For example, if automated methods were used to collect information from the experts and if the experts could be assembled at one time, it could be possible to create prototype checklists in one day. 


\subsection{INTRODUCTION}

This report presents the results of a study to test a new method for developing descriptions of hard-to-price products. This study is a follow-up study to a project that developed and tested the method on PC software products. ${ }^{1}$ This project focused on the telecommunications industry.

This report has the following sections. Section 2.0 presents a concise description of the method tested in this project. Section 3.0 presents the results (as augmented by several appendices). The report concludes with observations and recommendations in Section 4.0.

\subsection{METHOD}

The purpose of this method is to provide a structured approach based on sound behavioral science principles to elicit from experts several types of information about hard-to-price products in order to quickly and efficiently build checklists for those products. Commodity analysts (CAs) at BLS would be responsible for using the method and assembling panels of experts to provide the required information. Implementing the method entails the following ten steps.

1. Choose an industry or product area that needs product checklist development.

2. Develop a sampling frame of experts in the appropriate industry. Sampling frames can be developed from: lists of members of appropriate professional organizations; lists of attendees of appropriate professional meetings, and contacting people directly in appropriate professional networks.

3. Contact a sample of experts to participate in three information elicitation tasks. How this is done depends upon the sampling frame chosen. For example, mailing requests

${ }^{1}$ See Bruce Tonn and Fred Conrad. 1995. Product Features Elicitation Project. ORNL/M4598, Oak Ridge National Laboratory, Oak Ridge, TN, July. 
along with the first task to potential participants is most expeditious if one has an extensive mail list.

4. Prepare and send to the experts the first task, Product Listing. The purpose of this task is to elicit from a group of experts lists of names of products in their industry, what companies produce the products, and how familiar the experts are with each listed product. Either generic product names can be elicited or specific product names.

5. Cull the list of products provided by the experts to the 100 most mentioned and most familiar products. A group of experts as small as 20 could provide several hundred products. Only 100 are needed for the second task.

6. Prepare and send to the experts the second task, Product Grouping. The purpose of this task is to elicit from the experts what products fall into similar product categories (analogous to BLS entry level items or ELI's). Each expert is asked to put each product into a group. There is no limit to how many groups or how many products need to be in a group.

7. Conduct multi-dimensional scaling. The results of Task 2 needed to be coded into $100 \times 100$ matrices, one matrix for each subject. There is one row for each of the 100 products covered in Task 2 and one column for each of these 100 products. The 1's in the matrices indicate that the product represented by the row and the product represented by the column were grouped together by the expert. 0's indicate that the products were not in the same group. These data are submitted to SAS or a similar statistical package that has a multi-dimensional scaling procedure. This procedure produces multidimensional scale scores for each product. These scores represent positions of the products in a multidimensional space. It is recommended that the first three scores be used, plotted and interpreted to see which products are close to each other in the multi-dimensional space. Save these scores in a data set that has 100 records, one record per product with three multidimensional scaling score variables.

8. Conduct cluster analysis on the product grouping data to place all 100 products into an appropriate number of clusters. Specifically, a cluster analysis needs to be run on the 100 product records with the three scale scores. The number of clusters that balances 
statistical precision and common sense grouping of products should be chosen. These clusters then form the basis of potential new and/or revised ELI's.

9. Prepare and send to the experts the third task, Product Comparison (or Repertory Grid). In this task, for each product cluster chosen (one may choose not to use all the clusters resulting from task three because of time and other constraints), each expert is asked to answer open-ended questions about why a series of two products from a cluster are similar and dissimilar. If specific product names were not elicited in the previous tasks (i.e., only general product labels are available), each expert can be asked to list two specific products by product name and then answer the open-ended questions.

10. Use the results of task three to prepare checklists for each product cluster encompassed in the third task. Even with only a small number of experts participating in the third task, this method can result in a rich set of product descriptors for many potentially new or revised ELI's. At this point, it is the task of the CA to use his or her knowledge of checklist requirements to distill important product characteristics from the data and synthesize this information into draft product checklists.

\subsection{RESULTS}

This section describes the results of a project that focused on the telecommunications industry. The reasoning and results follow the ten steps introduced above.

\section{Choose an industry or product area that needs product checklist development.}

The industry chosen for this project was the telecommunications industry. This industry was chosen because it is very dynamic and a very important part of the U.S. economy. The industry and its products are currently being addressed by BLS, so the results of this project could be compared to existing efforts. 


\section{Develop a sampling frame of experts in the appropriate industry.}

This proved to be a challenging task. Over the course of the project several sampling frames were used. The first frame was a list of telecommunications experts that were part of a Department of Defense panel. This frame was augmented by a list of telecommunications experts in the Oak Ridge, Tennessee, area known to the project team. These two sources of potential subjects proved insufficient, as finding people to agree to participate in this project was quite difficult.

Three other approaches were adopted. First, project team members visited in person several places of business in Knoxville, Tennessee, to recruit subjects. Second, the authors of this report attended the 1997 COMNET conference in Washington, DC. This conference draws together several thousand telecommunications experts. The authors attempted to recruit participants at this conference but this also proved difficult. The third approach, which was the most successful, was to develop a mailing list of potential subjects from the COMNET conference participants list and business cards picked up in the exhibition area. Primary letters and secondary and tertiary followup letters eventually resulted in sufficient participation to complete this project.

\section{Contact a sample of experts to participate in three information elicitation tasks.}

As noted above, it was difficult to find telecommunications experts to participate in this project. There were several reasons. Many people simply failed to respond to phone calls, e-mails, and letters. Many of those who did stated they were too busy to participate. Some felt that they were not 'expert' enough to participate. With respect to the in-person visits to several businesses in Knoxville, it was hard to find the 'right' person, as project team members were continually shunted from one office to another. Many that we talked to in person had difficulty understanding the purpose of the project. The larger number of people contacted by a mass mailing overcame these problems to the extent needed to successfully complete the project. 
4. Prepare and send to the experts the first task, Product Listing.

The form for this task is found in Appendix A. It was completed by 14 subjects.

5. Cull the list of products provided by the experts to the 100 most mentioned and most familiar.

A list of approximately 360 products resulted from Task 1 . The raw data are found in Appendix B. This list was culled to 100 . These 100 products are included in the Task 2 form, which is found in Appendix $\mathrm{C}$. One interesting observation about this data is that by-and-large the products provided by the experts were generic (e.g., routers, fax/modems). In the PC software products project cited above, the experts provided specific product names (e.g., WordPerfect, SAS). It appears that respondents will provide generic names for products in more broadly defined industries, such as telecommunications, and specific product names for narrowly defined industries, such as PC software. Either approach is fine. However, respondents need guidance on whether to provide generic or specific product names. A mixing of approaches will cause data analysis difficulties in the following steps.

6. Prepare and send to the experts the second task, Product Grouping.

As noted above, the Task 2 form is found in Appendix C. It was filled out by 15 subjects.

\section{Conduct multi-dimensional scaling.}

Fifteen 100x100 matrices, one for each subject, were used in this data analysis portion of the method and project. A multi-dimensional scaling procedure in SAS was run on these data. This procedure resulted in 3 strong dimensions: 
- Dimension 1 - This dimension captures the systems aspects of the product. On one end, there are telecommunications infrastructure products, such as routers, lan switches, modems, and lan bridges. At the other end are telecommunications services, such as voicemail, paging services, and debit cards. In the middle of this scale are midware products, such as laptop PCs, pagers, and hand-held global positioning devices.

- Dimension 2 - This dimension captures the data nature of the product. On one end of this scale are traditional analog phone services, such as phones, pagers, PBX systems, and answering machines. At the other end of this scale are traditional digital computing products, such as web browsers, lan switches, and frame relay systems. In the middle of the scale are hybrid products such as ISDN service and fiber cable.

- Dimension 3 - This dimension captures the functionality of the products. In this case, products fall into two major groups, traditional personal computing products (e.g., digital assistants, palmtops) at one end and traditional telecommunications industry products (e.g., fract 1 lines, ISDN routers) at the other end.

8. Conduct cluster analysis on the product grouping data to place all 100 products into an appropriate number of clusters.

The scores for each of the 100 products were output into a second data set. These one hundred records were run through a cluster analysis procedure, in this case FASTCLUS in SAS. Several analyses with different numbers of clusters were run. The best fit with the data, in our judgment, involved fourteen clusters. This number of clusters resulted in an $R^{2}$ of 0.88 . In general, the products fell into 'recognizable' categories, such as: data and video services, consumer telephone equipment, networking options, phone services, computer network technologies, PC software, PC hardware, telecommunications system hardware, and computer networking hardware. The MDS and cluster analysis results are in Appendix D.

9. Prepare and send to the experts the third task, Product Comparison (or Repertory Grid). 
The form for Task 3 is found in Appendix E. As indicated, only eight of the fourteen clusters were included in Task 3. In addition, the subjects were asked to specify two products in each of the eight clusters to make similarity and dissimilarity comparisons. Seven experts returned the Task 3 forms. No expert provided data for every cluster. Typically, each expert only provided information for one or two clusters. Every cluster, though, had data from two experts. Two clusters had four experts providing information. The raw data are found in Appendix F.

10. Use the results of task three to prepare checklists for each product cluster encompassed in the third task.

Appendix $\mathrm{G}$ contains draft product descriptions for the eight clusters included in Task 3. Two observations are worth mentioning about these descriptions. First, they need to be augmented with more detail and specification structures before they could be considered checklists and used in the field. Second, many of the product description headings were similar to headings developed in the PC software project. This indicates that there may be important cross-cutting product characteristics in many of the dynamic computer and telecommunications based industries.

\subsection{OBSERVATIONS AND CONCLUSIONS}

The following observations follow the ten elements of the method first laid out in Section 2.0. These observations and conclusions are based mostly on the project that is the focus of this report, the telecommunications project, but also on the initial PC software project and on some knowledge of a third effort that is focusing on the nursing home industry.

1. Choose an industry or product area that needs product checklist development.

The method appears flexible enough to be useful for almost every industry that is characterized by dynamic and/or hard-to-price products. However, the choice of the level of 
aggregation of the industry to focus on is very important. The first study, which entailed PC software, entailed a much more specifically defined industry than the second study, which focused on the telecommunications industry. As a result, data provided by experts were much more specific in the first case than the second.

A second observation is that the method works best in contexts where products have specific names (such as PC software products) or widely recognizable generic names (e.g., cellular phones). There would be some difficulty in applying the method to an industry where products do not have specific names or recognizable generic names. This seems to be a problem being encountered in the nursing home study, where this industry appears to have few if any discernable 'products' as opposed to a portfolio of services which is tailored for each individual customer.

\section{Develop a sampling frame of experts in the appropriate industry.}

This step in the method is key. In other words, finding names of people to participate in the project is one-half the battle. It was a source of difficulty for the telecommunications industry. However, it appears that working through professional organizations and/or professional conference organizers to build sampling frames is a viable approach. Working with the organizers of the COMNET conference was successful for the telecommunications project. On the PC software project, everyone on a list-serve associated with the Social Science Computing Association was contacted, with great success.

\section{Contact a sample of experts to participate in three information elicitation tasks.}

Getting experts to participate can also be a source of difficulty. In other words, recruiting subjects is the other half of the battle. Because of this difficulty, the elapsed time from beginning to end of the telecommunications project was quite long. Actually processing the data collected during Tasks 1, 2, and 3 took only a few days by comparison. Conducting the project solely through the mail could, even in the best of circumstances, require many months, especially if 
second and third reminders need to be sent to prospective participants. Using the Internet or directing subjects to a website to complete forms may reduce this time somewhat, but not much if subjects are given the customary several weeks to complete each task.

For future projects, it is suggested that consideration be given to another design which entails bringing together ten to twenty experts for a one-day 'workshop' to complete all the tasks during the same day. We have found that the method can produce very good product characteristics with this few number of experts. Using automated support, experts could complete task 1 in fifteen minutes or so and commodity analysts could have a culled list of 100 products within an hour. Experts could conduct the product grouping task (2) on-line. Creation of $100 \times 100$ matrices from this data could be automated, as could the ensuing MDS and cluster analyses. This task could be turned around also in an hour. Finally, task 3 could be supported by automated techniques to record answers. The experts could work in small groups to fashion product descriptions. In onehalf a day's work, very good product characterizations could be produced. While this approach would probably be more expensive if honorariums were paid to the subjects, it would be more time efficient.

\section{Prepare and send to the experts the first task, Product Listing.}

This task is fairly straightforward. However, some additional thought needs to be given to better explain the purpose of the project and what is entailed. This is especially important if the first task form is included with the initial letter of contact.

\section{Cull the list of products provided by the experts to the 100 most mentioned and most familiar.}

This task is also straightforward. In the first two studies, there were many specific and generic products that were mentioned multiple times. The familiarity ratings help, too. Choosing all products with multiple mentions and then working down the list of singularly mentioned products 
from most to least familiar till 100 products is reached is very effective. Some judgement is needed, though, in cases where products are not highly differentiated from one another (such as WordPerfect 5.0 and WordPerfect 6.0).

6. Prepare and send to the experts the second task, Product Grouping.

This is also a straightforward task. Illustrating what the subjects need to do with an example is useful. We did not encounter any subjects who had problems with this task, once they decided to do it.

\section{Conduct multi-dimensional scaling.}

Preparing the $100 \times 100$ matrices is straightforward. CAs can be given clear instructions about how to use SAS to conduct the MDS and cluster analyses. A special SAS application could be developed as well. Advice to CA's from people with expertise in MDS and cluster analysis might be needed to help decide how many dimensions to include in the analysis and how many clusters to settle upon. However, we believe that in most cases, these decisions will be obvious.

8. Conduct cluster analysis on the product grouping data to place all 100 products into an appropriate number of clusters.

See discussion under Step 7.

9. Prepare and send to the experts the third task, Product Comparison (or Repertory Grid).

This is a very key task. The challenge of this task is to choose product clusters for which product checklists could eventually be made (if they don't exist already). It does not make sense to choose clusters which, while containing a group of products that can be distinguished from all the others, is too small with respect to its role in the economy and/or would cost more to collect 
data on than its worth to a price index. For example, this might be the case for some of the PC software clusters, such as statistical analysis software. On the other hand, the clusters chosen should not be too broad, because then the checklist would be rife with inconsistencies and definitional problems. Value-added networks might be such a case in the telecommunications study. So, CAs need to bring to this task some additional insights into the scope of the industry, and the range of potential ELI's that could be considered.

10. Use the results of task three to prepare checklists for each product cluster encompassed in the third task.

While this task may take some time for CAs, it is generally very straightforward. Their expertise in using raw product data to create checklists will make this an easy task. Difficulties may be encountered, however, in cases where the data do not help CAs determine which specifications could be $A$ specs versus $B$ specs, etc.

\subsection{ACKNOWLEDGMENTS}

The authors wish to thank Sheila Moore and Danny Moore (unrelated) for their help with this project. They were particularly helpful in contacting businesses in the Knoxville area. We also wish to thank Jenna Tonn for helping to input Task 2 information into the matrix formats. We wish to thank Mark Austen for running the statistical analyses and to Jean Peretz for making Mark's time available to this project. Kim Tripp provided information on telecommunication experts in the Department of Defense. Finally, we wish to thank the participants in this project. 


\section{APPENDICES}

Appendix A: Task 1 Form

Appendix B: Task 1 Raw Data

Appendix C: Task 2 Form

Appendix D: Multi-dimensional Scaling and Cluster Analysis Results

Appendix E: Task 3 Instructions

Appendix F: Task 3 Raw Data

Appendix G: Draft Product Descriptions

A - 1 



\section{APPENDIX A: TASK 1 FORM}

\section{Bureau of Labor Statistics Survey}

for

Telecommunications Industry

\section{Listing Task Instructions}

Please provide the names for ten or more $(10+)$ specific telecommunications products that you are familiar with that are sold DIRECTLY to consumers. We would like as broad a range of products as possible, so please do not limit yourself to only those products that you work with. Please provide the vendor name, if you know it. Also, please indicate how familiar you are with the product on a scale of 1-5, where 1 indicates low familiarity and 5 indicates high familiarity. This task should require 10-15 minutes of your time. Thank you very much for your assistance on this first task.

NAME

OF PRODUCT
VENDOR

(if applicable and known)
FAMILIARITY

WITH PRODUCT

(1=LOW, 5=HIGH)

1.

2.

3.

4.

5.

6.

7.

8.

9.

$$
\text { A - } 3
$$


10.

11.

12.

13.

14.

15.

16

17.

18.

19.

20.

21.

22.

23.

24.

25.

A - 4 
APPENDIX B: TASK 1 RAW DATA

Products
Routers
TA/Router
TA/Router
Router
Router
Cisco 7000 Router
Routers
ISDN Router
Pagers
Pagers
Pager
Paging Service
Pager
Pager
Pager
Paging Service
Pager
Pagers
Pagers
Paging Equip.
Pager
Pagers
Narrowband pager
Telephone
Telephone
Telephone
Cordless telephone
Telephone for home use
Telephone
Telephone
Cordless Phone (analog)
Multi-Button Phone
Multi-Button Phone
Multi-Button Phone
Phone
900 MHZ Cordless Phone
Phones

Vendors

Cisco

Gandalf

Shira

Cisco

Ascend

Cisco

Cisco et.al

Fasallon

Motorola

?

Motorola

Skytel and others

Motorola

Motorola

Motorola

Skytel,

Motorola

STS

Bogen

Motorola, Nixxo

Many

Motorola

Multiple

Meridian et.al

Duofone

various

Various

Various

Bell South

Toshiba

AT\&T

GTE

Panasonic

AT\&T

Panasonic

AT\&T, Panasonic
Familiarity with Product ( $1=$ low, $5=$ high)

4

2

2

4

3

4

3

5

3

2

5

4

4

2

3

4

5

5

5

3

5

3

5

4

5

5

4

4

5

4

4

4

4

4

5

3

5

A - 5 
Telephone

Cordless phone

Cordless Phone

Standard wired telephone

Hands-Free headset

Do-it-yourself home telephone

wire, jacks, extension cords, etc.

KHT 500 telephone

Push Button Phone

Wireless Phone

Fax (standalone or plug in cord)

Fax

Fax Machine

Fax Machine

Fax Machines

Fax machines

Fax Machines

Fax Machines

Fax/Modem/Phone Sharing Device

Digital Fax \& FC connections

« "

(4)

(4)

a $)$

4

6 ")

Answering machine

Answering machine

Answering machines

Phone/Answering Machine

Answering Machine

Cellular phone (analog)

Car Phone

Cellular phones

Cellphone
AT\&T

Panasonic

AT\&T

Bell operating companies?

4

5

4

2

GE

Motorola

5

4

5

Canon et.al 4

Sharp 3

Hewlett Packard, Canon,

Ricoh,etc.

Hewlett-Packard 5

HP 5

$? \quad 2$

Command Communications $\quad 4$

Enhanced Throughout Cellular 1

Motorola 1

Toshiba 1

Megahertz 1

Mitsubishi 1

ORA Electronics 1

U.S. Wireless Data, Inc. 1

Pacific Communications

Sciences, Inc. 1

Sierra Wireless 1

Panasonic 5

Panasonic 4

AT\&T, Panasonic 5

GE $\quad 5$

AT\&T $\quad 4$

Motorola 2

Motorola 3

Ericcson 5 
Cellphone

Cellular Phone

" "

Cellular Phones

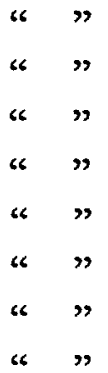

Mobile Phone

Mobile Phone

cellular telephone

Cellular Phone

Digital Cellular Phone

Cellular Phones

Cellular Phone

Cellular Telephones

Cell Phone

Cellular Phones

Cellular Phone Accessories

«

4,

" "

\& "

《6

Cellular Phone Antennas

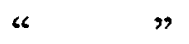

a "

"

Mobile Base Station

Mobile Base Station

Pocket PDA

PCS phone (digital)

PCS Phone

" $"$
Nokia

Audiovox, Motorola,

Ericsson, Nokia

Motorola

4

Uniden

Nokia

Ericsson

Oki Telecom

Audiovox

GE

Mitsubishi

NEC

Qualcomm

Molsar

Motorola

Motorola

Sony Qualcomm

Nynex

Motorola

Motorola, Nokia, etc

“

Motorola, Nokia

Sell Star

Superior Cellular Products

Advanced Fox Cellular 3

Walnex Technologies 2

S-L Electronics 2

EDCO, Eastern Dynamics

Co. LTD.

Antenna Specialists 5

STI-CO Industries 1

Valor Wireless Products 1

Mobile Mark Communications 1

Encsson 2

Nortel 3

US Robotics Pilot 3

Motorola 2

Sony/Qualcomm, Motorola, Ericsson, Nokia

$$
\text { A - } 7
$$


(US Domestic Long distance

Telephone service)

AT\&T, MCI, Sprint, etc. 4

Local telephone service

Long Distance Service

IT long distance service

Long Distance Svc.

Local Service

Basic Dial Tone

Long Distance Serv.

Bell Atlantic (in Baltimore area) 4

AT\&T

3

Telegroup

" “ 5

Bell Atlantic 3

Bell South 5

AT\&T 5

One Plus Long Distance Service STS 5

Cellular telephone service $\quad$ Various 4

$\begin{array}{lll}\text { Cellular Service } & \text { ATT Wireless } & 4\end{array}$

Cellular service

Cellular Service

Personal Communications Service

(similar to cellular)

Cell One 5

Sprint Spectrum (In Baltimore and

Washington, D.C. areas) 4

International long distance

Telephone service

AT\&T, MCI, others 4

Telephone Lines

RBOCS

Calling Card

Debit card program

Calling cards

Pre Paid Card

Prepaid Cellular

Calling Card

Prepaid Calling Cards

$\begin{array}{ll}\text { AT\&T } & 4 \\ \text { “ } " & \\ \text { “ } " & 5 \\ \text { STS } & 5 \\ \text { “ } & 5 \\ \text { STS } & 5\end{array}$

Voicemail

Bell Atlantic 2

Voice Mail

STS

Wild Fire-Automated Secretary

Voice Mail

STS

5

Octel

Caller ID Display

Bell Operating Companies $\quad 2$

Caller ID Device

Call back service

TT Systems

Modems

Multiple

Hayes et.al.

Zoom

Modems

28.8 Modem

US Robotics

4

Digital Modem

Bit Surfer Pro 
Wireless modem

Wireline modem

ADSL Modem

ADSL Modem

Modem Internal

Modem

Modem communications

Modem (28.8 kbps e.g.)

Impact IQ modem

Ricochet modem

Lan Plus Modem

Modem

Modems

Cable Modem

Wireless Modem

Wireline Modem

PC Modem

33.6 Kpbs Modems

Fax/Modem

Fax/Modem

Ethernet Switches

Lan Switch

ATM Switch

PBX Switch

PBX

Telephone System, PBX (Large)

“ ",key(small/med)

Switches

Ethernet Hubs

Intelligent HUB

Lan Hubs

Bridge (Lan)

Lan Bridge

Net. Mgmt.

Cat. 5 Cable

Copper cable

Fiber cable
US Robotics 5

Cobbal Village 4

Amati 3

Orjsit 3

IBM 5

Digicom Sys. 5

US Robotics 5

US Robotics 4

3 Com 5

Metricom 5

3 Com 5

" " 5

Cisco Systems, US Robotics 5

" " 4

Motorola 5

USR 3

US Robotics 5

USR, Hayes, Microcom 5

Data Fax Modem 5

Hayes 3

3 Com 4

IBM Cisco 5

Fore 5

Nortel 3

AT\&T 2

Northern Telec.(Nortel) 5

" " 3

Lucent et.al 2

Multiple $\quad 5$

IBM 5

Cabletron/3Com/Bay $\quad 3$

3 Com 4

IBM 5

$\begin{array}{ll}\text { Vertel } & 3\end{array}$

Mohawk \& Belden 5

Amixter et.al 1

$3 \mathrm{M}$ et.al $\quad 1$ 
Multiple 5

Software

Multiple 3

cc:Mail (e-mail software) $\quad$ Lotus/IBM\&Microsoft 5

MS Mail

Microsoft 4

MS Exchange

Fax software

Microsoft 4

Fax software

Fax Software

Procomm Plus

PC Anywhere

Windows 95

Windows 3.11

Fax Serve

Windows NT

COMit for Windows

Delrina et.al

Symantec, Microsoft 5

? 2

Datastorm 4

Symantec 5

Microsoft 5

Microsoft 5

Cheyenne 4

Microsoft 4

Tradewind Software 5

Symantec 5

PCAnywhere 32

? 3

$? \quad 3$

Qmodem

Remote 2

Crosstalk 4

Crosstalk

Exceed for Windows

Email Software

Crosstalk

Hummingbird 4

FTP 3

SmartCom

Hayes

Ocean Isle 4

ReachOut

ProComm

OnNet

SmartTerm

? 3

FTP Software 4

$? \quad 3$

Wireless Network Products

Multiple 4

Laptop computers

Laptop

IBM

2

Palmtop computer

CASIO

4

Apple

Hewlett Packard

Palmtop PC

Portable Laptop

Newton organizer

(Pentium)

Personal computers

Laptop computers

Computers

IBM, Compaq, NEC,

Apple Computer 2

Toshiba, etc. 5

Compaq, Gateway 5

Compaq, Toshiba 5

Apple, etc. 3 
Personal digital assistant

PDA

Satellite dish

Satellites

Satellite Dish

Satellite TV dishes

DBS satellite dish

Satellite dishes

Digital Satellite

Satellite Disk

GDS handheld unit

Time + Frequency systems

Cable TV Service--basic channels

Cable Service

Cable TV

Television

Radio

Direct-to-home satellite TV Service

Cable converter

Cable Decoder

Computer on-line information

service(1), (2)

Internet access provider service

Internet Access

ISP

Internet Service Provider

Internet Service

Online Services

CompuServe

America Online
Apple 2

Apple, US Robotics 2

RCA 5

STS 5

RCA 2

Phillips 1

RCA 2

Direct TV (RCA) 4

RCA 2

Sony 5

5

Oderics 5

TCI, others nationally 4

Time Warner 5

Local Franchisers 4

Sony 5

Mitsubishi 5

4

Radio Shack 3

Zenith 3

Compuserve, America Online(AOL) 4

various

4

ATT, MindSprings, etc.

IGN 5

AOL 3

Advantis 5

Netcom

AOL, CompuServe, Prodigy,

Spry Mosaci

4

IBM

.

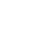

(2)

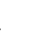

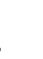

5

5

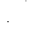

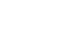

4

5

5

4

3.

3




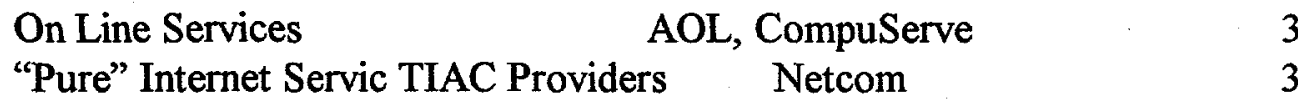

ISDN Term. Adapter $\quad$ Motorola 4

$\begin{array}{lll}\text { ISDN Terminal Adapter } \quad \text { Motorola } & 3\end{array}$

ISDN Adapters $\quad$ ISDN.TEK, Megaherty USR 3

ISDN Access Device $\quad$ " " " 4

Lan Streamer Adapter $\quad$ IBM 5

$\begin{array}{lll}\text { Fract. T-1 Verilink } & 4\end{array}$

directly via telephone company leased line $\quad 2$

$\begin{array}{lll}\text { Leased Line } & \text { ATT } & 3\end{array}$

$\begin{array}{lll}\text { ISDN Service } & \text { RBOCS } & 4\end{array}$

Terminal Server 3 Com 3

Lan Server Novell 3

Wan Server $\quad$ Cisco Sys. 3

Front end Processor $\quad$ IBM 5

Network computer $\quad$ Oracle, Sun 3

$\begin{array}{lll}\text { Atone Junction Box } & \text { Asalte } & 3\end{array}$

$\begin{array}{lll}\text { Protocol Converter } & \text { Andrews }\end{array}$

$\begin{array}{lll}\text { Remote Access device } & \text { Shiva } & 5\end{array}$

Web TV set top box 1

Web TV 3

Web TV . Philips/Magnavox/Sony 3

Web Browsers Netscape 3

Browsers $\quad$ Netscape/Microsoft $\quad 5$

$\begin{array}{lll}\text { Web browsers } & \text { Netscape } & 4\end{array}$

Alarm System connected

Microwave

transmitters/receivers

satellite, transmitters/receivers

Frame Relay

Hughes 1

X.25 Service

“ " $\quad 4$

“ $" 5$

ISDN service

Groupwise

Novell 
Video-Conferencing

Telecommunications Device for the

Deaf (TDD)

Portable CB Radio

Cobra

Data Services

Lexis

box that allows you to receive T.V. listings

via cell phone call

Wireless Wide Area Network

Ardis

Value-Added Network

Sprint

X.25 Cards

Elcon

PBX

Panasonic

Pan-Way

Panduit

Mini-Cam

“ "

Pentascaner

Microtest

CSUID8V

Adtran

5

OTDR

Servor

3

\&

Winle Device

Casio

DSUS

Win Frame

Lucent et.al

WinView

Citrix

Win Frame

Citrix

Co Session

Citrix

Winport

Lantastic/Artisoft

2

GSM

Lansource

4

ADSL

France Telecom

4

"Orchestrata" Multipoint Control

France Telecom

5

5

Unit (MCU)

Compunctix

5

"Contex"Audio Conferencing SystemCompuntix

MCS (MCU)

System 70 (MCU)

System 80 (MCU)

Concorde 4500 Coder

System 4000 Coder

PCS 100 Coder

Radiance Coder
Videoserver

Multilink

Multilink

Picturetel

Picturetel

Picturetel

CLI

.

.

.


Z240 Coder

Multiland Plus (IMUX)Inverter

Multiplexer

ISV512 (IMUX)

VC7000 (Coder)

Data Multiplexer

ISDN Interface Group

Clid Telephones

Network Services

IVR Systems

Telephone jacks, Cat.5

Automatic Call Distributor

Data Network Concentrator

UPS Systems

SMR/ESMR
Zydacon

4

Ascend 4

Adtron 4

BT 4

Coastcom 4

ADTRAN 4

Nortel 3

BellSouth 4

Octel 2

Nortel 5

“" $" 4$

Bay Networks 3

BEST 4

Uniden, Motorola 3 


\section{APPENDIX C: TASK 2 FORM}

Dear :

Thank you very much for providing names of telecommunications products for Task 1 of this project. The number of telecommunications products received numbered over 300 . We have reduced this number to 100 for this task, Task 2.

The purpose of Task 2 is to group the 100 telecommunications products into groups of products that are similar to each other. Product grouping is an important task for BLS because price changes must be tracked and reported for groups of products that have similar characteristics. Failure to do this may bias inflation and productivity estimates.

Thus, your task is to group the 100 telecommunications products listed below, that is to place products in the same group that you believe belong together. There is no right or wrong answer; we are simply interested in how you would group these products on the basis of what you know about them. The criteria you use to decide if a product belongs in the same group as other products, are entirely up to you. You can make groups as large or as small as you like. You can define as many categories as you wish.

We would like you to use one of two techniques to indicate your grouping judgments to us. First, you can number each product in the list where the number corresponds to a category. Simply place a category number to the left of each product. If you do this, it might be useful (but it is not necessary) to create a numbered list of product category names so that the number you place next to an individual product also corresponds to a category name. A blank list is provided just below these instructions where you can enter category names. Please add product category names to the list as you go along and please feel free to re-categorize products as necessary.

Here is an example. Imagine a set of letters, $A$ through $J$. If you decide that $A, E$ and $I$ belong in the same group -- let's say group \#1 -- then you would place a 1 in the column to the left of these products and you might label the group "vowels." You would enter "vowels" in the line following the ' 1 ' in the blank list below the instructions. Similarly, if B, C, D, F, G, H and J belong in another category -- let's say category \#2 -- then you would enter a 2 in the left column next to these products, and if you have a name for the group -- let's say consonants -- you would place it in the line following ' 2 ' in the blank list.

As an alternative way to convey your grouping decisions, you can use your text editor to physically move the software products into groups. If you choose this approach, it is not necessary place numbers beside the product names. If you wish to label the groups, that may be helpful, but again, it is not necessary. Just make sure that each group of products is separated from the other groups by blank lines or some other sign when you send your results back. 
If a product is totally unfamiliar to you and you cannot place it into a group, please place it into a group labeled something like "unknown."

The data you provide will be used to statistically determine the number and nature of product categories represented by the software products you helped provide. Task 3 will focus on eliciting features of products.

Please complete this task and return the results by ??????

Telecommunications Products Category Names

1.

2.

3.

4.

5.

6.

7.

8.

9.

10.

11.

12.

13.

14.

15.

16.

17.

18.

19.

20.

Telecommunications Products to Place into Telecommunications Product Categories

Category Number Product

Router

ISDN Router

Pagers

Paging Service

Narrowband pager

Telephone

A - 16 
Cordless telephone

Hands-Free headset

Wireless Phone

Fax Machine

Answering machine

Cellular phone (analog)

Digital Cellular Phone

Cellular Phone Antennas

Mobile Base Station

US Domestic Long distance Telephone service

Local telephone service

Cellular telephone service

Personal Communications Service

International long distance Service

Debit card program

Prepaid Calling Cards

Voicemail

Caller ID Display

Call back service

28.8 Modem

Wireless modem

ADSL Modem

Lan Plus Modem

Cable Modem

Fax/Modem

Ethernet Switches

Lan Switch

ATM Switch

PBX Switch

PBX

Ethernet Hubs

Lan Bridge

Cat. 5 Cable

Copper cable

Fiber cable

cc:Mail (e-mail software)

Fax software

Windows 95

Windows NT

SmartTerm

Palmtop computer

Newton organizer

Personal computers 
Personal digital assistant

Satellite dish

Satellites

GPS handheld unit

Cable Service

Direct-to-home satellite TV Service

Cable converter

Computer on-line information service

Internet Service Provider

ISDN Term. Adapter

Lan Streamer Adapter

Fract. T-1

Leased Line

ISDN Service

Terminal Server

Lan Server

Wan Server

Front end Processor

Network computer

Atone Junction Box

Protocol Converter

Web TV set top box

Web TV

Web Browsers

Microwave transmitters/receivers

Frame Relay

X.25 Service

Lotus Notes

Video-Conferencing

Telecommunications Device for the Deaf (TDD)

Portable CB Radio

Data Services

Wireless Wide Area Network

Value-Added Network

X.25 Cards

Pentascaner

Win Frame

"Orchestrata" Multipoint Control Unit (MCU)

"Contex" Audio Conferencing

MCS (MCU)

System 80 (MCU)

System 4000 Coder

Z240 Coder 
Multiland Plus (IMUX)Inverter

Multiplexer

ISDN Interface Group

IVR Systems

Automatic Call Distributor

Data Network Concentrator

UPS Systems

SMR/ESMR 


\title{
APPENDIX D: MULTI-DIMENSIONAL SCALING AND CLUSTER ANALYSIS RESULTS
}

\author{
The SAS System 8 \\ 09:19 Wednesday, November 12, 1997
}

ASTCLUS Procedure: Replace=FULL Radius $=0$ Maxclusters $=13$ Maxiter $=1$

Initial seeds

\begin{tabular}{rrrr} 
Cluster & DIM1 & DIM2 & DIM3 \\
\hline 1 & -1.34577 & 0.50707 & 1.01425 \\
2 & 1.58507 & 0.21439 & 0.28332 \\
3 & -0.18443 & -0.78451 & 1.45930 \\
4 & -0.64128 & -0.88970 & -1.46761 \\
5 & -0.67726 & 1.36622 & -0.66120 \\
6 & 0.59667 & -0.30515 & -1.56225 \\
7 & -0.12041 & -1.70876 & -0.29479 \\
8 & -1.29503 & -0.78400 & 0.89745 \\
9 & 1.31227 & -0.70566 & 0.83686 \\
10 & 1.09606 & -1.30475 & -0.03638 \\
11 & -1.73152 & -0.17823 & -0.32554 \\
12 & 0.66609 & 1.26990 & -0.93463 \\
13 & 0.66503 & 1.38892 & 0.62741
\end{tabular}

Criterion Based on Final Seeds $=0.2321$

A - 20 
cluster summary

\begin{tabular}{|c|c|c|c|}
\hline Cluster & Frequency & $\begin{array}{r}\text { RMS std } \\
\text { Deviation }\end{array}$ & $\begin{array}{c}\text { Maximum Distance } \\
\text { from Seed } \\
\text { to Observation }\end{array}$ \\
\hline 1 & 11 & 0.2612 & 1.1110 \\
\hline 2 & 8 & 0.2853 & 0.6858 \\
\hline 3 & 4 & 0.2283 & 0.5465 \\
\hline 4 & 11 & 0.2195 & 0.6294 \\
\hline 5 & 14 & 0.1751 & 0.8492 \\
\hline 6 & 4 & 0.2639 & 0.5491 \\
\hline 7 & 9 & 0.2594 & 0.7691 \\
\hline 8 & 10 & 0.2143 & 0.5288 \\
\hline 9 & 14 & 0.1951 & 0.6332 \\
\hline 10 & 3 & 0.1441 & 0.2724 \\
\hline 11 & 2 & 0.3791 & 0.9286 \\
\hline 12 & 5 & 0.3082 & 0.7052 \\
\hline 13 & 6 & 0.3583 & 1.0061 \\
\hline
\end{tabular}

FASTCLUS Procedure: Replace $=$ FULL Radius $=0$ Maxclusters $=13$ Maxiter $=1$

\begin{tabular}{crr} 
Cluster & $\begin{array}{c}\text { Nearest } \\
\text { Cluster }\end{array}$ & $\begin{array}{c}\text { Distance Between } \\
\text { Cluster Centroids }\end{array}$ \\
\hline 1 & 8 & 0.7742 \\
2 & 9 & 1.1330 \\
3 & 8 & 1.0491 \\
4 & 7 & 1.1039 \\
5 & 12 & 1.3766 \\
6 & 4 & 1.1391 \\
7 & 4 & 1.1039 \\
8 & 1 & 0.7742 \\
9 & 10 & 0.9106 \\
10 & 9 & 0.9106 \\
11 & 4 & 1.3802 \\
12 & 2 & 1.2169 \\
13 & 2 & 1.2889
\end{tabular}

Statistics for Variables

\begin{tabular}{lcccr} 
Variable & Total STD & Within STD & R-Squared & RSQ/(1-RSQ) \\
\hline DIM1 & 1.023700 & 0.214135 & 0.961495 & 24.970881 \\
DIM2 & 1.000148 & 0.254977 & 0.942884 & 16.508308 \\
DIM3 & 0.986704 & 0.252940 & 0.942251 & 16.316265 \\
OVER-ALL & 1.003702 & 0.241318 & 0.949178 & 18.676351
\end{tabular}

A - 21 
Pseudo F Statistic $=136.96$

Approximate Expected Over-All R-Squared $=0.86057$

Cubic Clustering Criterion $=14.854$

WARNING: The two above values are invalid for correlated variables.

The SAS System 10

09:19 Wednesday, November 12, 1997

\begin{tabular}{|c|c|c|c|c|c|}
\hline FASTCLUS & Procedure: & Replace=FULL & Radius $=0$ & Maxclusters $=13$ & Maxiter $=1$ \\
\hline & & Cluste & c Means & & \\
\hline & cluster & DIM1 & DIM2 & DIM3 & \\
\hline & 1 & -1.35676 & 0.39027 & 0.95568 & \\
\hline & 2 & 1.43886 & 0.52037 & 0.43118 & \\
\hline & 3 & -0.41152 & -0.51687 & 1.52169 & \\
\hline & 4 & -0.51266 & -0.89558 & -1.44463 & \\
\hline & 5 & -0.25842 & 1.50157 & -0.76617 & \\
\hline & 6 & 0.10802 & 0.02836 & -1.68665 & \\
\hline & 7 & -0.00885 & -1.55881 & -0.72011 & \\
\hline & 8 & -1.32968 & -0.37954 & 1.03302 & \\
\hline & 9 & 1.36798 & -0.56650 & 0.74329 & \\
\hline & 10 & 1.15080 & -1.23171 & 0.16056 & \\
\hline & 11 & -1.52795 & -0.29841 & -0.72516 & \\
\hline & 12 & 1.03955 & 1.08756 & -0.56866 & \\
\hline & 13 & 0.49602 & 1.38746 & 0.57440 & \\
\hline
\end{tabular}

A -22 
Cluster Standard Deviations

\begin{tabular}{rrrr} 
Cluster & DIM1 & DIM2 & DIM3 \\
\hline 1 & 0.100751 & 0.383103 & 0.218487 \\
2 & 0.130330 & 0.333411 & 0.340688 \\
3 & 0.227942 & 0.319930 & 0.045973 \\
4 & 0.152249 & 0.289837 & 0.193319 \\
5 & 0.221345 & 0.121833 & 0.167844 \\
6 & 0.381250 & 0.236842 & 0.086388 \\
7 & 0.252747 & 0.137797 & 0.344934 \\
8 & 0.180989 & 0.202597 & 0.252978 \\
9 & 0.110192 & 0.230193 & 0.221413 \\
10 & 0.061625 & 0.095142 & 0.222370 \\
11 & 0.287887 & 0.169972 & 0.565145 \\
12 & 0.298370 & 0.339259 & 0.284320 \\
13 & 0.434467 & 0.214709 & 0.387574
\end{tabular}

The SAS System 11

09:19 Wednesday, November 12, 1997

\begin{tabular}{|c|c|c|c|c|c|c|c|c|}
\hline $\begin{array}{l}\text { OBS } \\
\text { DIM3 }\end{array}$ & & $\begin{array}{l}\text { TYPE } \\
\text { CLŨSTER }\end{array}$ & TAN & $\mathrm{ME}$ & OBS & DIMI & & DIM2 \\
\hline & & ICRITERION & & & 1 & 0.46102 & & - \\
\hline & & 0.3 & 30229 & & & & & \\
\hline 55 & 3 & - CONFIG SATL_TVS & SATL_TVS - & -1.34577 & 0.50707 & 1.01425 & 10 & 0.1628 \\
\hline 50 & 3 & - CONFIG INT_SERV & INT_ $\bar{S} E R V-$ & -1.38605 & 0.14132 & 1.08227 & 10 & 0.23161 \\
\hline 46 & 3 & CONFIG PAGINN_SR & PAGIN_SR - & -1.40391 & 0.08316 & 1.08409 & 1 & 0.28812 \\
\hline 42 & 3 & CONFIG CEL SERV & CEL SĒRV - & -1.39298 & 0.14121 & 1.07642 & 1 & 0.23052 \\
\hline 25 & 3 & CONFIG CALIDDDIS & CAI IDDDIS - & -1.09472 & 1.24879 & 0.38548 & 11 & 1.11100 \\
\hline & 3 & VOICMAIL & VOICMAIL & 3 & -1.24576 & 61.00 & 0127 & $7 \quad 0.69224$ \\
\hline & 1 & 0.72315 & & & & & & \\
\hline & 17 & PHON_LNG & PHON_LNG & 17 & -1.39226 & 0.25028 & & 1.04621 \\
\hline 1 & & 0.12378 & & & & & & \\
\hline 1 & 18 & $\begin{array}{l}\text { PHON_LOC } \\
0.1237\end{array}$ & PHON_LOC & 18 & -1.39225 & 0.2502 & & 1.04622 \\
\hline 1 & 20 & $0.13280^{\text {P_CONSER }}$ & P_CONSER & 20 & -1.42145 & 0.24443 & & 1.02417 \\
\hline 1 & 22 & $\operatorname{caLBCK}_{0.18972}^{\text {CAL }}$ & CALBCK_S & 22 & -1.43177 & 0.18318 & & 1.02875 \\
\hline 1 & 23 & $\begin{array}{l}\text { PRPD_CAL } \\
0.13528\end{array}$ & PRPD_CAL & 23 & -1.41740 & 0.24203 & & 1.03242 \\
\hline 75 & 3 & CONFIG MICROWAV & MICROWAV & 1.30309 & 0.93138 & 0.48126 & 20 & 0.49918 \\
\hline 60 & 3 & CONFIG ISDN_TER & ISDN_TER & 1.56567 & 0.19141 & 0.41220 & 20 & 0.28973 \\
\hline 47 & 3 & CONEIG FBR_CBLE & FBR_CBLE & 1.27759 & 0.32304 & 1.07188 & 2 & 0.68528 \\
\hline 45 & 3 & - CONFIG ADSL_MOD & ADSI_MOD & 1.58507 & 0.21439 & 0.28332 & 2 & 0.31090 \\
\hline $33:$ & 3 & CONFIG CABL_MOD & CABL_MOD & 1.51076 & 0.53165 & 0.31307 & 2 & 0.14280 \\
\hline 30 & 3 & CONFIG LAN_MOD & LAN_MOD & 1.54749 & 0.20553 & 0.57051 & 2 & 0.30636 \\
\hline 7 & & CONFIG HS2 $88 M O D$ & HS28̄8MOD & 1.42294 & 0.82569 & -0.15388 & 20 & 0.68583 \\
\hline
\end{tabular}

$$
\text { A - } 23
$$




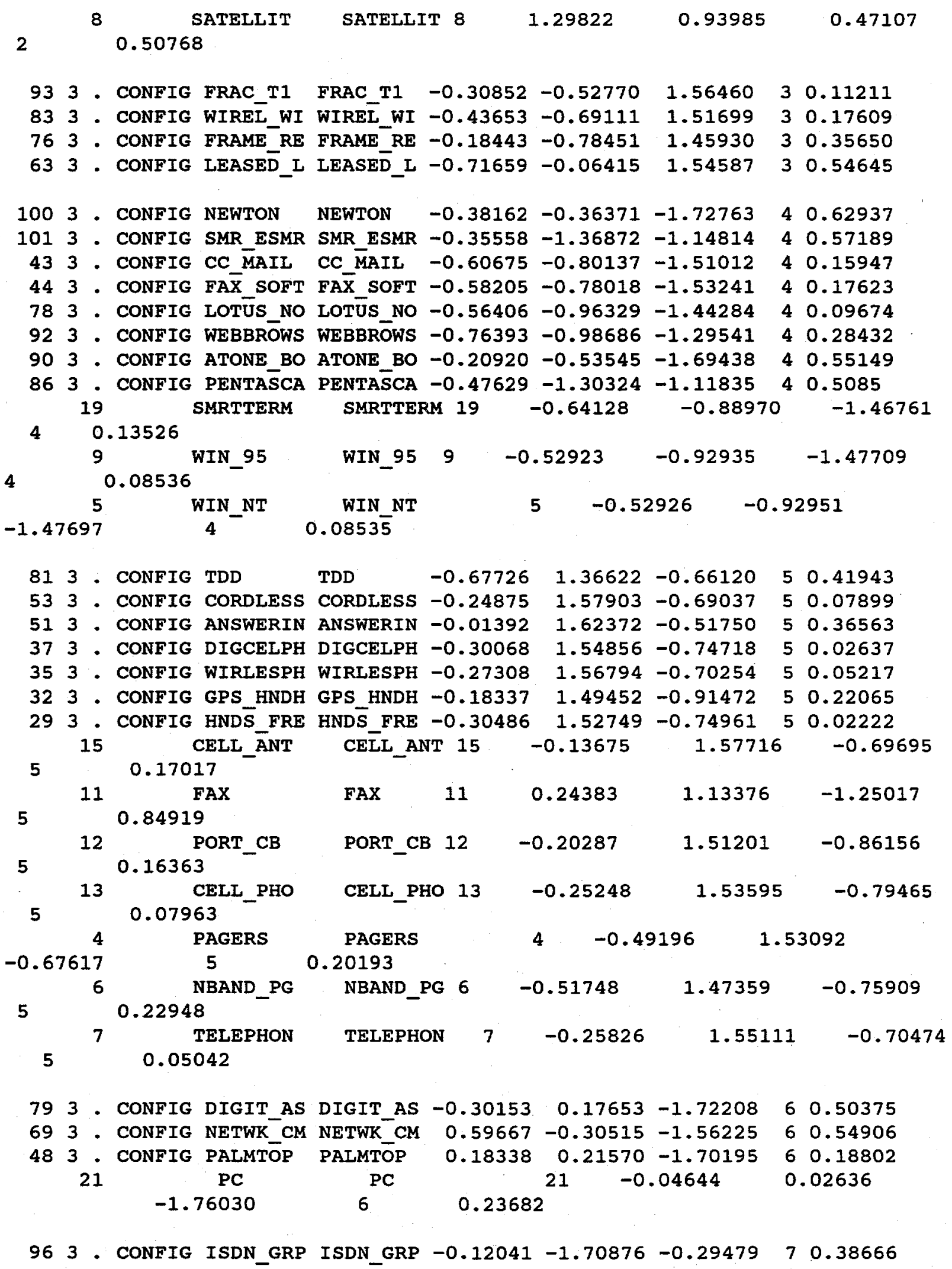




\begin{tabular}{|c|c|c|c|c|c|c|c|c|c|}
\hline 94 & 3 & CONFIG & IMUX_INV & IMUX_INV & 0.46566 & -1.67280 & -0.07373 & 7 & 0.76906 \\
\hline 91 & 3 & CONFIG & SYSTËM80 & SYSTEM8O & -0.05774 & -1.56008 & -0.85469 & 7 & 0.20503 \\
\hline 87 & 3 & CONFIG & WIN_FRAM & WIN_FRAM & -0.09724 & -1.63294 & -0.72500 & 7 & 0.10126 \\
\hline 88 & 3 & CONFIG & $\mathrm{ORCH}_{-} \mathrm{MCU}$ & ORCH_MCU & 0.09246 & -1.61535 & -0.72549 & 7 & 0.14444 \\
\hline 74 & 3 & CONFIG & SYST $\overline{4} 000$ & SYST $\overline{4} 000$ & 0.18044 & -1.23794 & -1.24137 & 7 & 0.72079 \\
\hline 67 & 3 & CONEIG & MCS & MCS & 0.01555 & -1.56810 & -0.83872 & 7 & 0.19243 \\
\hline 61 & & CONFIG & 2240_COD & Z240_COD & -0.09160 & -1.54048 & -0.92685 & 7 & .28431 \\
\hline 57 & & CONFIG & UPS & UPS & -0.46679 & -1.49283 & -0.80038 & 7 & .47010 \\
\hline 95 & 3 & CONFIG & CABL_SRV & CABL_SRV & -1.25128 & -0.12678 & 1.28606 & 8 & .4068 \\
\hline 82 & 3 & CONFIG & WEB_T $\mathrm{T} V$ & WEB_T $\bar{T} V$ & -1.44217 & -0.18378 & 1.02615 & 8 & .24764 \\
\hline 80 & 3 & CONFIG & VIDĒO_CO & VIDĒO_CO & -1.57297 & -0.24095 & 0.68208 & 8 & .43246 \\
\hline 73 & 3 & CONFIG & DATA_SER & DATA_SER & -1.18202 & -0.38460 & 1.24403 & 8 & .28664 \\
\hline 77 & 3 & CONFIG & X25_SERV & X25_SERV & -1.08786 & -0.58243 & 1.23018 & 8 & .37957 \\
\hline 85 & 3 & CONFIG & NETSRV_P & NETSRV_P & -1.14444 & -0.44115 & 1.26033 & 8 & 32247 \\
\hline 64 & 3 & CONFIG & ISDN_SER & ISDN_SER & -1.28300 & -0.24094 & 1.17952 & 8 & 24767 \\
\hline 62 & 3 & CONFIG & VALU_ADN & VALU_ADN & -1.29503 & -0.78400 & 0.89745 & 8 & .39380 \\
\hline 58 & 3 & CONFIG & ONL_INFO & ONL_INFO & -1.40246 & -0.50252 & 0.94539 & 8 & .12904 \\
\hline 41 & 3 & CONFIG & DEBITTCRD & DEBITCRD & 63554 & -0.30823 & 0.57898 & 8 & .52876 \\
\hline 84 & & CONFIG & LAN_ST_A & LAN_ST_A & & -0 . & 33026 & 9 & \\
\hline 99 & 3 & CONFIG & DA_N̄ETW̄K & DA_N̄ETW̄K & 1.21653 & -0.94271 & 0.75794 & 9 & 40581 \\
\hline 71 & 3 & CONEIG & PRŌTOC_C & PRŌTOC_C & 1.28415 & -0.77455 & 0.80157 & 9 & 0.23175 \\
\hline 68 & 3 & CONFIG & FRNT_EP & FRNT_EP & 1.55929 & -0.64622 & 0.14502 & 9 & 0.63315 \\
\hline 59 & 3 & CONFIG & X25_CARD & X25_CARD & 1.53934 & -0.38877 & 0.37423 & 9 & 0.44402 \\
\hline 56 & 3 & CONFIG & MULTIPLX & MULTIPLX & 1.44530 & -0.29930 & 0.80484 & 9 & 0.28489 \\
\hline 52 & & CONFIG & ISDN_ROU & ISDN_ROU & 1.44095 & -0.43376 & 0.76090 & 9 & 0.15249 \\
\hline 34 & 3 & CONFIG & LAN_SWIT & LAN_SWIT & 1.41098 & -0.54132 & 0.72991 & 9 & 0.05159 \\
\hline 31 & 3 & CONFIG & ETHERNET & ETHERNET & 1.41004 & -0.44387 & 0.78362 & 9 & 0.13577 \\
\hline 38 & 3 & CONFIG & ETHETHUB & ETHETHUB & 1.31227 & -0.70566 & 0.83686 & 9 & 0.17670 \\
\hline 39 & 3 & CONFIG & LANBRIDG & LANBRIDG & 1.32797 & -0.68405 & 0.83045 & 9 & 0.15171 \\
\hline 40 & 3 & CONFIG & CAT5CBLE & CAT5CBLE & 35025 & -0.17451 & 0.99531 & 9 & 0.46635 \\
\hline & 2 & & ROUTER & ROUTER & & $2 \quad 1.37$ & 7218 & & \\
\hline & & & & .13172 & & & & & \\
\hline & 10 & & ATM_SW & ATM_SW & 10 & 1.30993 & -0.48558 & & \\
\hline & & 0.22845 & & & & & & & \\
\hline 98 & 3 & CONFIG & TERM_SRV & TERM_SRV & & & & 10 & \\
\hline 70 & 3 & CONFIG & WAN_SERV & WAN_SERV & 1.13880 & -1.26627 & 0.11634 & 10 & 0.05739 \\
\hline 66 & 3 & CONFIG & LAN_SERV & LAN_SERV & 1.09606 & -1.30475 & -0.03638 & 10 & 0.21706 \\
\hline 97 & 3 & CONFIG & IVR_SYST & IVR_SYST & -1.32 & -0.41860 & -1.12478 & 11 & 0.92861 \\
\hline 89 & 3 & CONFIG & CONTEXAU & CONTEXXAU & -1.73152 & -0.17823 & -0.32554 & 11 & 0.00000 \\
\hline 72 & 3 & CONFIG & WEBTV_ST & WEBTV_ST & & & & 12 & \\
\hline 54 & 3 & CONFIG & FAX_MOD & FAX_MODD & 1.29386 & 0.99259 & -0.24747 & 12 & 0.59100 \\
\hline 49 & 3 & CONEIG & CBLE_CNV & CBLE_CNV & 1.34619 & 0.55466 & -0.79195 & 12 & 0.70515 \\
\hline 28 & 3 & CONEIG & WRLS_MOD & WRLS_MOD & 1.08782 & 1.17823 & -0.44984 & 12 & 0.30597 \\
\hline 24 & 3 & CONFIG & SATELLIT & SATELLIT & 0.80377 & 1.44240 & -0.41939 & 12 & 0.4474 \\
\hline & & & AUTCAL_D & & - & 1.03149 & 0.66828 & 13 & 1.00611 \\
\hline
\end{tabular}




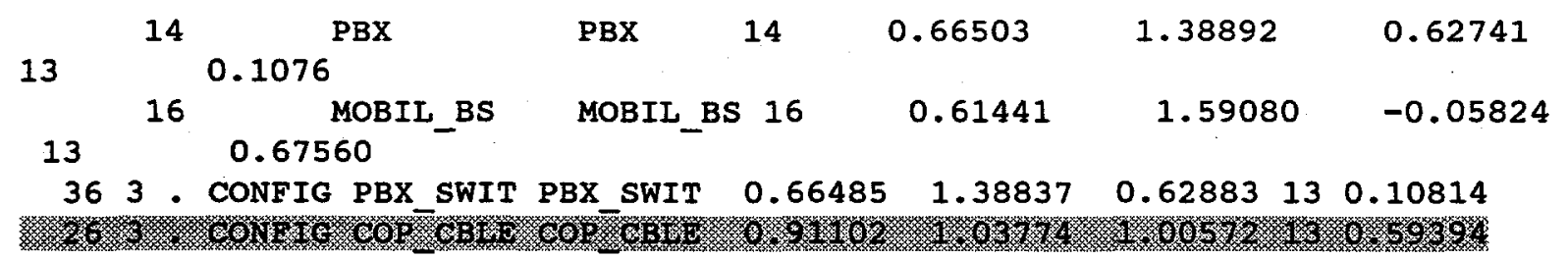

A -26 
$09: 19$ Wednesday, November 12,1997

FASTCLUS Procedure: Replace=FULL Radius=0 Maxclusters=14 Maxiter=1

Initial seeds

\begin{tabular}{rrrr} 
Cluster & DIM1 & DIM2 & DIM3 \\
\hline 1 & 1.09606 & -1.30475 & -0.03638 \\
2 & 1.58507 & 0.21439 & 0.28332 \\
3 & -0.76393 & -0.98686 & -1.29541 \\
4 & 0.59667 & -0.30515 & -1.56225 \\
5 & -0.67726 & 1.36622 & -0.66120 \\
6 & -0.12041 & -1.70876 & -0.29479 \\
7 & -0.18443 & -0.78451 & 1.45930 \\
8 & -1.34577 & 0.50707 & 1.01425 \\
9 & 1.31227 & -0.70566 & 0.83686 \\
10 & 0.66609 & 1.26990 & -0.93463 \\
11 & -1.73152 & -0.17823 & -0.32554 \\
12 & -0.30153 & 0.17653 & -1.72208 \\
13 & 0.66503 & 1.38892 & 0.62741 \\
14 & -1.29503 & -0.78400 & 0.89745
\end{tabular}

Criterion Based on Final seeds $=0.22618$ 
cluster summary

\begin{tabular}{rrrr} 
Cluster & Frequency & $\begin{array}{c}\text { RMS Std } \\
\text { Deviation }\end{array}$ & $\begin{array}{c}\text { Maximum Distance } \\
\text { from Seed } \\
\text { to Observation }\end{array}$ \\
\hline 1 & 3 & 0.1441 & 0.2724 \\
2 & 8 & 0.2853 & 0.6858 \\
3 & 9 & 0.1633 & 0.4966 \\
4 & 2 & 0 & 0.1175 \\
5 & 14 & 0.1751 & 0.8492 \\
6 & 9 & 0.2594 & 0.7691 \\
7 & 4 & 0.2283 & 0.5465 \\
8 & 11 & 0.2612 & 1.1110 \\
9 & 14 & 0.1951 & 0.6332 \\
10 & 5 & 0.3082 & 0.7052 \\
11 & 2 & 0.3791 & 0.9286 \\
12 & 5 & 0.2338 & 0.4577 \\
13 & 5 & 0.3794 & 1.0061 \\
14 & 10 & 0.2143 & 0.5288 \\
& \multicolumn{3}{c}{ The SAS System } \\
& $09: 19$ Wednesday, November 12,1997
\end{tabular}

FASTCLUS Procedure: Replace=FULI, Radius=0 Maxclusters $=14$ Maxiter $=1$

\begin{tabular}{ccr} 
Cluster & $\begin{array}{c}\text { Nearest } \\
\text { Cluster }\end{array}$ & $\begin{array}{c}\text { Distance Between } \\
\text { Cluster Centroids }\end{array}$ \\
\hline 1 & 9 & 0.9106 \\
2 & 9 & 1.1330 \\
3 & 6 & 1.0323 \\
4 & 12 & 0.7289 \\
5 & 10 & 1.3766 \\
6 & 3 & 1.0323 \\
7 & 14 & 1.0491 \\
8 & 14 & 0.7742 \\
9 & 1 & 0.9106 \\
10 & 2 & 1.2169 \\
11 & 3 & 1.3623 \\
12 & 4 & 0.7289 \\
13 & 2 & 1.2838 \\
14 & 8 & 0.7742
\end{tabular}

statistics for Variables

\begin{tabular}{lcccr} 
Variable & Total STD & Within STD & R-Squared & RSQ/(1-RSQ) \\
\hline DIM1 & 1.023700 & 0.205627 & 0.964898 & 27.488369 \\
DIM2 & 1.000148 & 0.251462 & 0.945086 & 17.210421 \\
DIM3 & 0.986704 & 0.249940 & 0.944261 & 16.940686 \\
OVER-ALL & 1.003702 & 0.236521 & 0.951737 & 19.719830
\end{tabular}


Pseudo F Statistic $=131.97$

Approximate Expected Over-All R-Squared $=0.87036$

Cubic clustering Criterion $=14.347$

WARNING: The two above values are invalid for correlated variables.

The SAS system

16

09:19 Wednesday, November 12,1997

FASTCLUS Procedure: Replace=FULL Radius=0 Maxclusters=14 Maxiter=1

Cluster Means

\begin{tabular}{rrrr} 
Cluster & DIM1 & DIM2 & DIM3 \\
\hline 1 & 1.15080 & -1.23171 & 0.16056 \\
2 & 1.43886 & 0.52037 & 0.43118 \\
3 & -0.56094 & -0.99469 & -1.38544 \\
4 & 0.52885 & -0.30515 & -1.56225 \\
5 & -0.25842 & 1.50157 & -0.76617 \\
6 & -0.00885 & -1.55881 & -0.72011 \\
7 & -0.41152 & -0.51687 & 1.52169 \\
8 & -1.35676 & 0.39027 & 0.95568 \\
9 & 1.36798 & -0.56650 & 0.74329 \\
10 & 1.03955 & 1.08756 & -0.56866 \\
11 & -1.52795 & -0.29841 & -0.72516 \\
12 & -0.15108 & -0.09612 & -1.72127 \\
13 & 0.50302 & 1.38746 & 0.57440 \\
14 & -1.32968 & -0.37954 & 1.03302
\end{tabular}

Cluster standard Deviations

\begin{tabular}{rrrr} 
Cluster & DIM1 & DIM2 & DIM3 \\
\hline 1 & 0.061625 & 0.095142 & 0.222370 \\
2 & 0.130330 & 0.333411 & 0.340688 \\
3 & 0.112674 & 0.205875 & 0.158005 \\
4 & 0.095918 &. &. \\
5 & 0.221345 & 0.121833 & 0.167844 \\
6 & 0.252747 & 0.137797 & 0.344934 \\
7 & 0.227942 & 0.319930 & 0.045973 \\
8 & 0.100751 & 0.383103 & 0.218487 \\
9 & 0.110192 & 0.230193 & 0.221413 \\
10 & 0.298370 & 0.339259 & 0.284320 \\
11 & 0.287887 & 0.169972 & 0.565145 \\
12 & 0.224710 & 0.335852 & 0.025789 \\
13 & 0.485370 & 0.214709 & 0.387574 \\
14 & 0.180989 & 0.202597 & 0.252978
\end{tabular}

A -29 
The SAS system

09:19 Wednesday, November 12, 1997

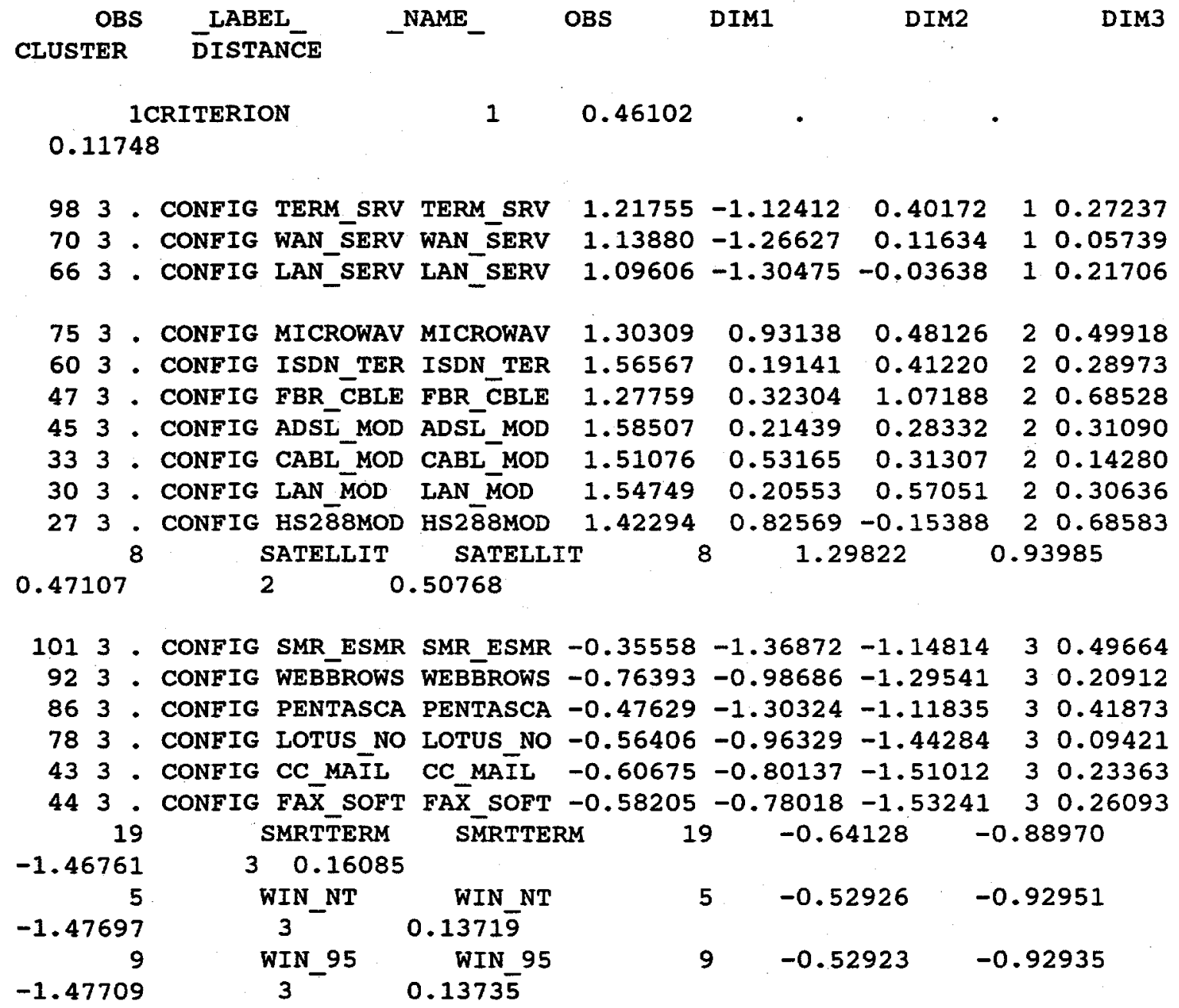

\begin{tabular}{|c|c|c|c|c|c|c|c|c|c|}
\hline 69 & 3 & CONFIG & NETWK_CM & NETWK_CM & 0.59667 & -0.30515 & -1.56225 & 4 & 0.06782 \\
\hline 81 & 3 & CONFIG & TDD & TDD & -0.67726 & 1.36622 & -0.66120 & 5 & 0.41943 \\
\hline 53 & 3 & CONFIG & CORDLESS & CORDLESS & -0.24875 & 1.57903 & -0.69037 & 5 & 0.07899 \\
\hline 51 & 3 & CONFIG & ANSWERIN & ANSWERIN & -0.01392 & 1.62372 & -0.51750 & 5 & 0.36563 \\
\hline 37 & 3 & CONFIG & DIGCELPH & DIGCELPH & -0.30068 & 1.54856 & -0.74718 & 5 & 0.02637 \\
\hline 35 & 3 & CONFIG & WIRLESPH & WIRLESPH - & -0.27308 & 1.56794 & -0.70254 & 5 & 0.05217 \\
\hline 32 & 3 & CONFIG & GPS_HNDH & GPS_HNDH - & -0.18337 & 1.49452 & -0.91472 & 5 & 0.22065 \\
\hline 29 & 3 & CONFIG & HNDS_FRE & HNDS_FRE - & -0.30486 & 1.52749 & -0.74961 & 5 & 0.02222 \\
\hline & 15 & & CELL_ANT & CELI_ANT & IT 15 & -0.13 & 3675 & 1.57 & 7716 \\
\hline 0.69 & 9695 & & $5 \quad 0.170$ & 017 & & & & & \\
\hline & 11 & & FAX & FAX & 11 & 0.2 & 4383 & 1.13 & 3376 \\
\hline 1.25 & 5017 & & 5 & 0.84919 & & & & & \\
\hline & 12 & & PORT_CB & PORT_CB & 12 & -0.20 & 0287 & 1.5 & 1201 \\
\hline-0.8 & 5156 & & 5 & 0.16363 & - & & & & \\
\hline
\end{tabular}




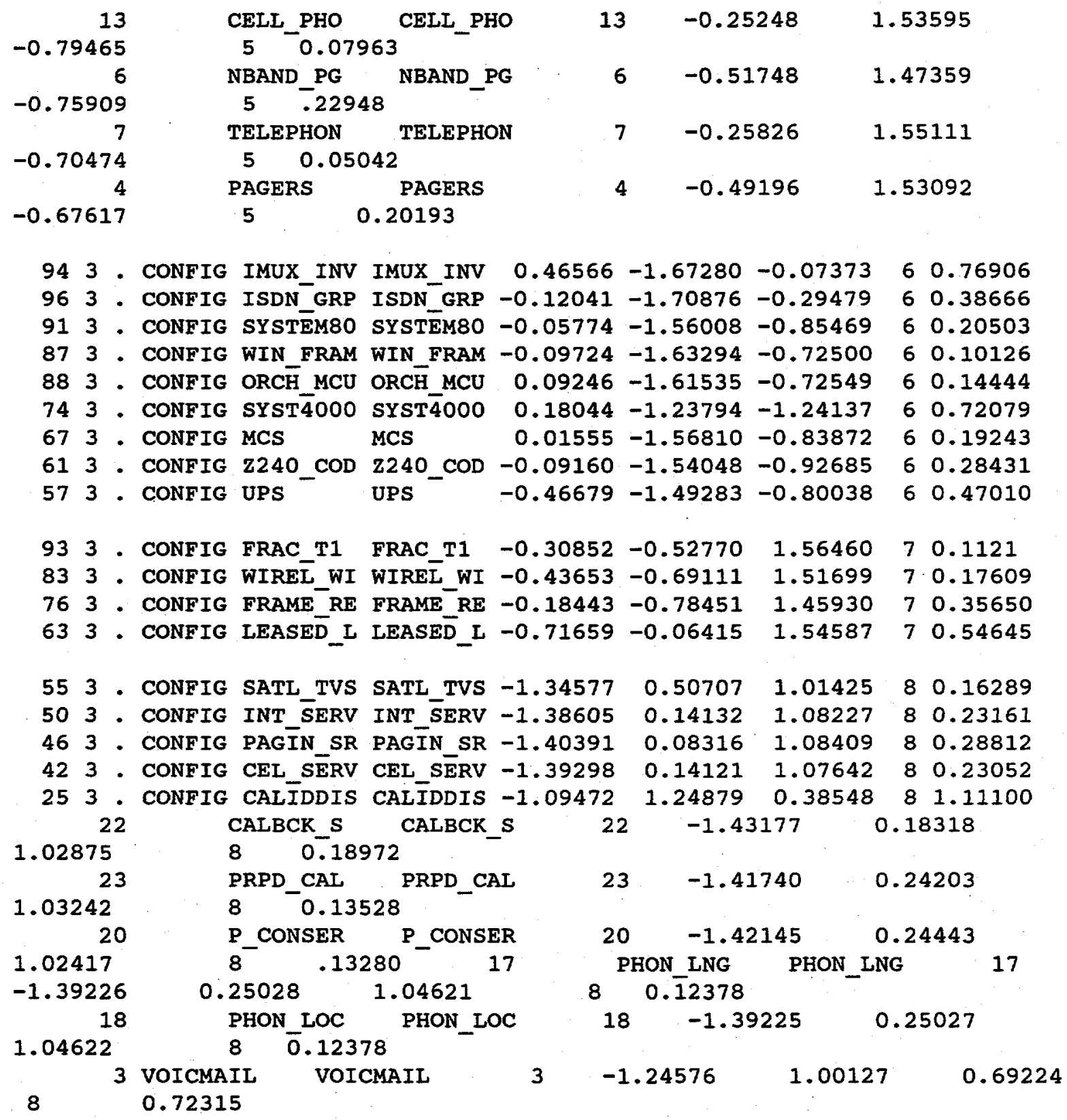

993 . CONFIG DA NETWK DA NETWK 843 . CONFIG LAN ST A LAN ST A

713 . CONFIG PROTOTOC C PROTOTOC C 683 . CONFIG FRNT E $\bar{P}$ FRNT E $\bar{P}$ 383 . CONFIG ETHETHUB ETHETHUB 393 . CONFIG LANBRIDG LANBRIDG 403 . CONFIG CAT5CBLE CAT5CBLE 343 . CONFIG LAN SWIT LAN SWIT 313 . CONFIG ETHERNET ETHERNET 0.80626
2 2

$$
\begin{array}{ccccc}
1.21653 & -0.94271 & 0.75794 & 9 & 0.40581 \\
1.17154 & -0.95977 & 0.83026 & 9 & 0.44812 \\
1.28415 & -0.77455 & 0.80157 & 9 & 0.23175 \\
1.55929 & -0.64622 & 0.14502 & 9 & 0.63315 \\
1.31227 & -0.70566 & 0.83686 & 9 & 0.17670 \\
1.32797 & -0.68405 & 0.83045 & 9 & 0.15171 \\
1.35025 & -0.17451 & 0.99531 & 9 & 0.46635 \\
1.41098 & -0.54132 & 0.72991 & 9 & 0.05159 \\
1.41004 & -0.44387 & 0.78362 & 9 & 0.13577 \\
2 & 1.37318 & -0.45092
\end{array}
$$




\begin{tabular}{|c|c|c|c|c|c|c|c|c|c|}
\hline & 10 & & ATM_SW & ATM SW & 10 & 1.30 & 9993 & -0.48 & \\
\hline .948 & 388 & & $9-$ & $22845^{-}$ & & & & & \\
\hline 59 & 3 . & CONFIG & X25_CARD & X25_CARD & 1.53934 & -0.38877 & 0.37423 & 9 & 0.44402 \\
\hline 56 & 3 & CONFIG & MULT̄IPLX & MULTTIPLX & 1.44530 & -0.29930 & 0.80484 & 9 & 0.28489 \\
\hline 52 & 3 & CONFIG & ISDN_ROU & ISDN_ROU & 1.44095 & -0.43376 & 0.76090 & 9 & 0.1524 \\
\hline 54 & 3 & CONFIG & FAX MOD & FAX MOD & 9386 & 0.99259 & -0.24747 & 710 & \\
\hline 49 & 3 & - CONFIG & CBLE_CNV & CBLĒ_CNV & 619 & 0.55466 & -0.79195 & 510 & 515 \\
\hline 28 & 3 & - CONFIG & WRLS_MOD & WRIS_MOD & 1.08782 & 1.17823 & -0.44984 & 110 & 0.30597 \\
\hline 243 & 3. & CONEIG & SATEL $\bar{L} I T$ & SATELĪIT & 0.80377 & 1.44240 & -0.41939 & 10 & \\
\hline 72 & 3 . & - CONFIG & WEBTV_ST & WEBTV_ST & & 1.26990 & 3463 & 310 & \\
\hline 97 & 3 . & CONFIG & IVR_SYST & IVR_SYST & -1.3 & -0.41860 & 478 & 11 & \\
\hline 89. & 3 & CONFIG & CONT⿱亠幺XXU & CONTEXAU & -1 & -0 & 554 & 411 & \\
\hline 100 & 3 & CONFIG & NEWTON & NEWTON & 62 & -0 & 763 & 12 & \\
\hline 90 & 3 & - CONFIG & ATONE BO & ATONE BO & -0.20 & 53545 & 9438 & 12 & \\
\hline 79 & 3 & - CONFIG & DIGIT_AS & DIGIT_AS & -0 & 53 & 208 & 312 & 140 \\
\hline 48 & 3 & CONFIG & PALMTŌP & PALMTŌP & 0.18338 & 0.21570 & -1 & 512 & 576 \\
\hline & 21 & & PC & PC & 2 & & & 0.0 & \\
\hline 1.76 & 5030 & & 12 & 0.16575 & & & & & \\
\hline 65 & 3 & - CONFIG & AUTCAL_D & AUTCAL_D & & & & $\begin{array}{l}813 \\
\end{array}$ & \\
\hline 36 & 3 & - CONFIG & PBX_SWITT & PBX_SWIT & 0.6 & 1.38837 & 883 & 313 & 314 \\
\hline 26 & 3 & - CONFIG & COP_CBLE & COP_CBLE & 0.91102 & 1.03774 & 1.00572 & 213 & 9394 \\
\hline & 16 & & MOBII__BS & MŌBII_E & BS $\quad 16$ & 0.6 & & 1.5 & \\
\hline 0.05 & 5824 & & $13 \quad 0.67$ & 560 & & & & & \\
\hline & 14 & & PBX & PBX & 1 & 0.6 & & 1.3 & \\
\hline .627 & & $1:$ & & .10764 & & & & & \\
\hline 85 & 3 & CONFIG & NETSRV_P & NETSRV_P & 144 & & & 14 & \\
\hline 82 & 3 & CONFIG & WEB_TV & WEB_TV & -1.4 & -0 & & 14 & \\
\hline 80 & 3 & - CONFIG & VIDĒO_CO & VIDĒO_CO & -1.5 & & & 14 & \\
\hline 77 & 3 & - CONFIG & X25_SERV & X25_SERV & & & & 14 & \\
\hline 73 & 3 & CONFIG & DATĀ_SER & DATA__SER & & & 3 & 14 & \\
\hline 9 & 3 & CONFIG & CABL_SRV & CABL_SRV & & & 8606 & 14 & 584 \\
\hline 6 & 3 & CONFIG & ISDN_SER & ISDN_SER & & & 17952 & 14 & 767 \\
\hline 62 & 3 & CONFIG & VALU_ADN & VALU ADN & -1.295 & -0 & 0.89745 & 14 & 380 \\
\hline 58 & 3 & CONFIG & ONL_INFO & ONL INFO & -1.4 & -0.50252 & 94539 & 14 & 0.1 \\
\hline 41 & 3. & - CONFIG & DEBITCRD & DEBITTCRD & -1.63554 & -0.30823 & 0.57898 & $8 \quad 14$ & 0.52876 \\
\hline
\end{tabular}




\section{APPENDIX E: TASK 3 INSTRUCTIONS}

Dear:

Please find a few minutes in the next few days to complete the enclosed exercise. This is the last task being asked of experts in the telecommunications field such as yourself for this project. The first two tasks involved listing and grouping telecommunications products, respectively. This final task is, by far, the most important of the three because it draws directly upon your expertise and knowledge to help describe the features of telecommunications products. Product descriptions provided by yourself and other experts will be compiled to create summary product descriptions that can be used by the Bureau of Labor Statistics in its processes to calculate the Consumer Price Index and other price indices.

I want to thank those of you who have completed one or both of the previous two exercises. Now is your chance to finish what you have begun. For those of you who have not yet contributed, now is your chance to help out on this most important task. Please carefully read over the instructions on the enclosed sheet. If you are interested in receiving a copy of the results of this project, please indicate this in the appropriate place on the exercise sheet. Do not hesitate to contact me if you have any questions. Please send back the filled out exercise sheet by XXXX.

Sincerely,

Bruce E. Tonn 


\section{DIRECTIONS}

Below and on the other side of this sheet are eight types of telecommunications products. For each product type, list two specific products of that type (under P1 and P2, respectively). Then, for each product couple $\{\mathrm{P} 1$ and $\mathrm{P} 2\}$, indicate what makes products $\mathrm{P} 1$ and $\mathrm{P} 2$ similar to each other and enter the reasons in the row(s) labeled "S" and then indicate what makes products $\mathrm{P} 1$ and $\mathrm{P} 2$ different from each other and enter the reasons in the row(s) labeled "D". Feel free to add extra lines for your reasons. Only provide similarity and difference explanations for those product couples that you are familiar with. If you want, please indicate which version of the product you are comparing. Please review the following example before proceeding.

Do you want a copy the report that describes the results of this project?

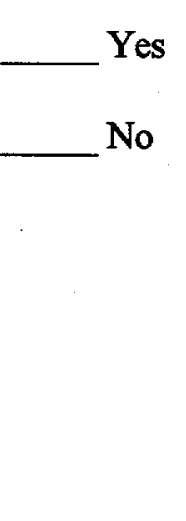

Example Product Description Exercise

\section{Product Type: Television Game Shows}

\section{P1: Jeopardy $\quad$ P2: Let's Make a Deal}

S: Both give away money and prizes.

Both had male hosts.

Both are half-hour shows.

Both have low budget sets and production costs.

D: In P1, the contestants have to be smart; in P2, the contestants have to be outrageously dressed.

In P1, winning is based on knowledge; in P2 winning is based on luck.

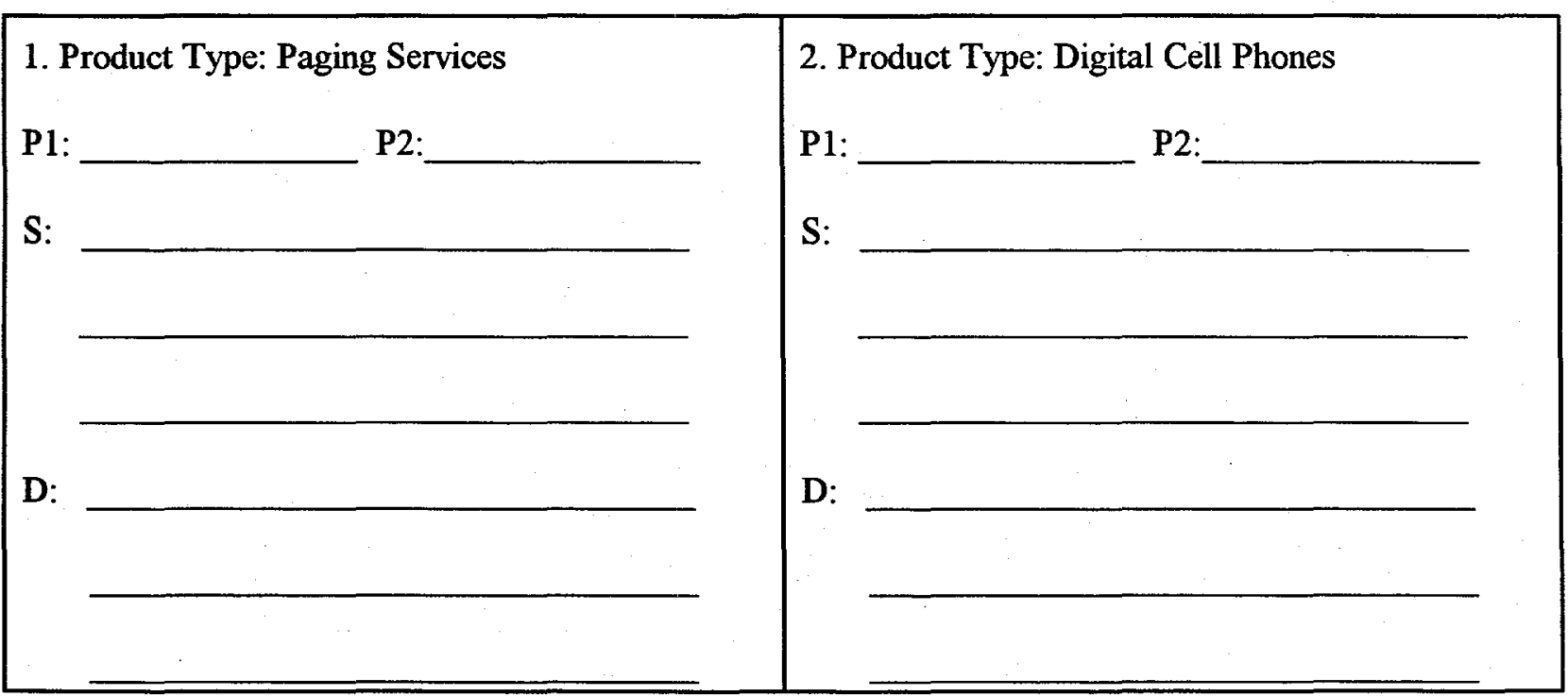




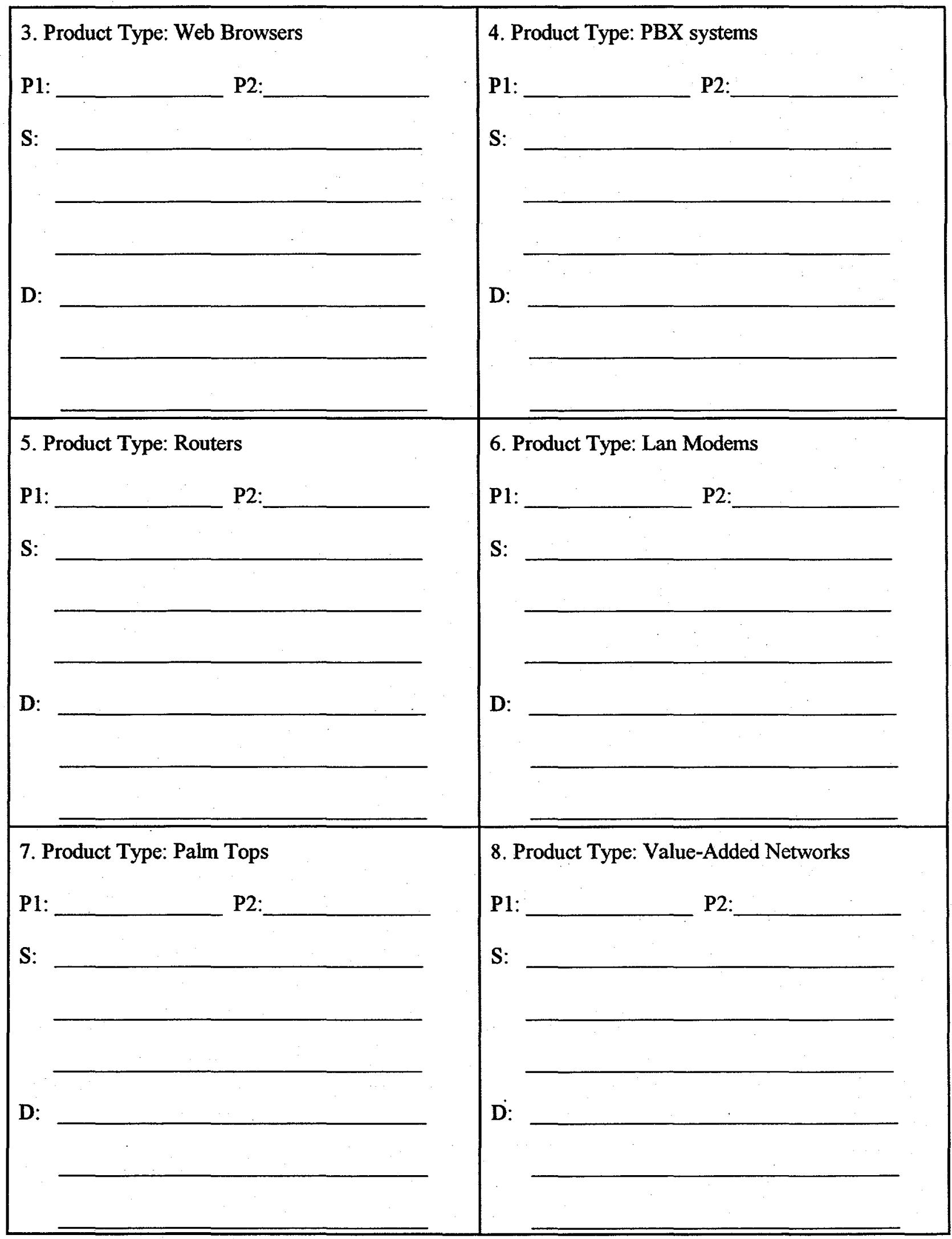

A - 35 


\section{APPENDIX F: TASK 3 RAW DATA}

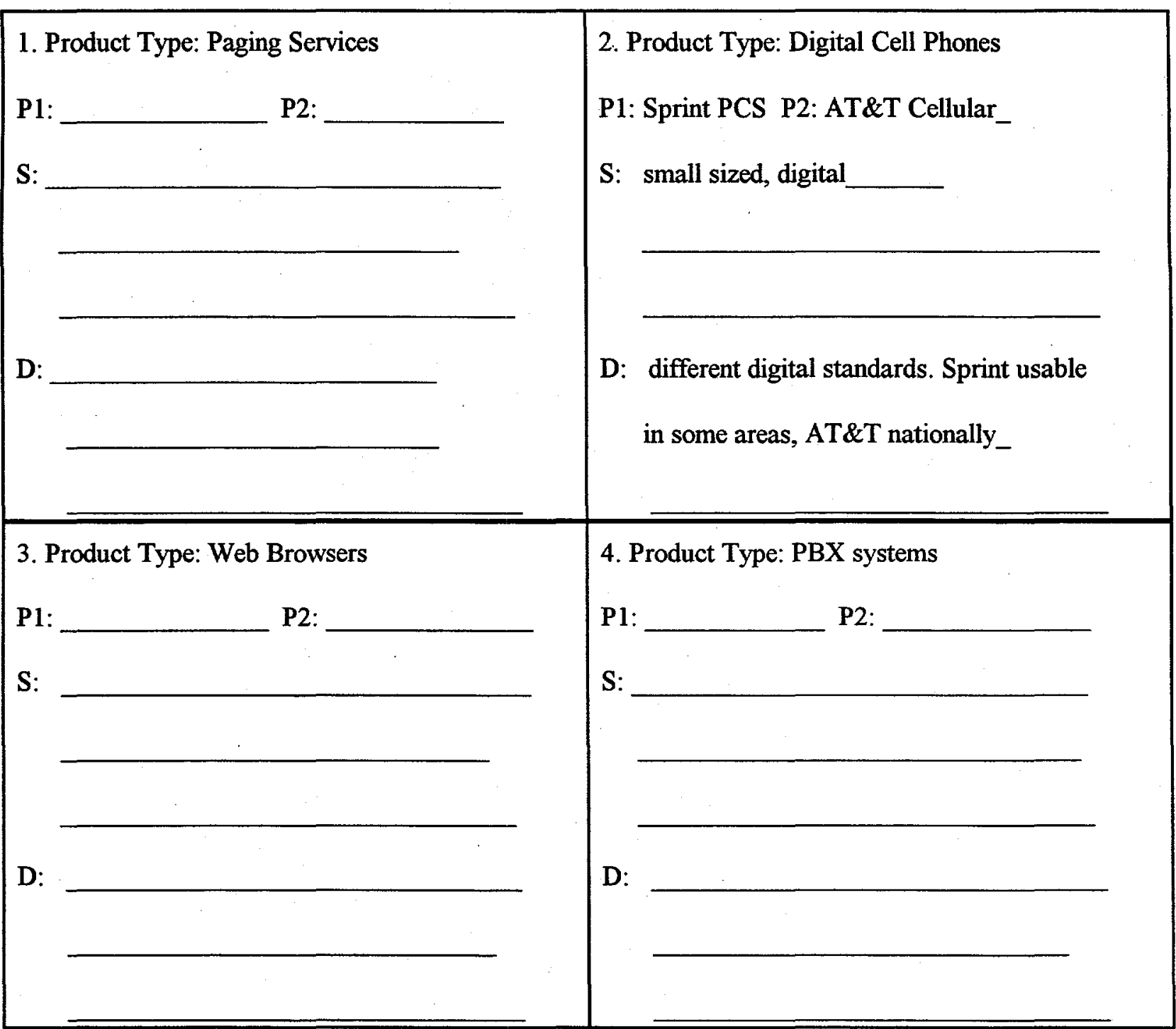




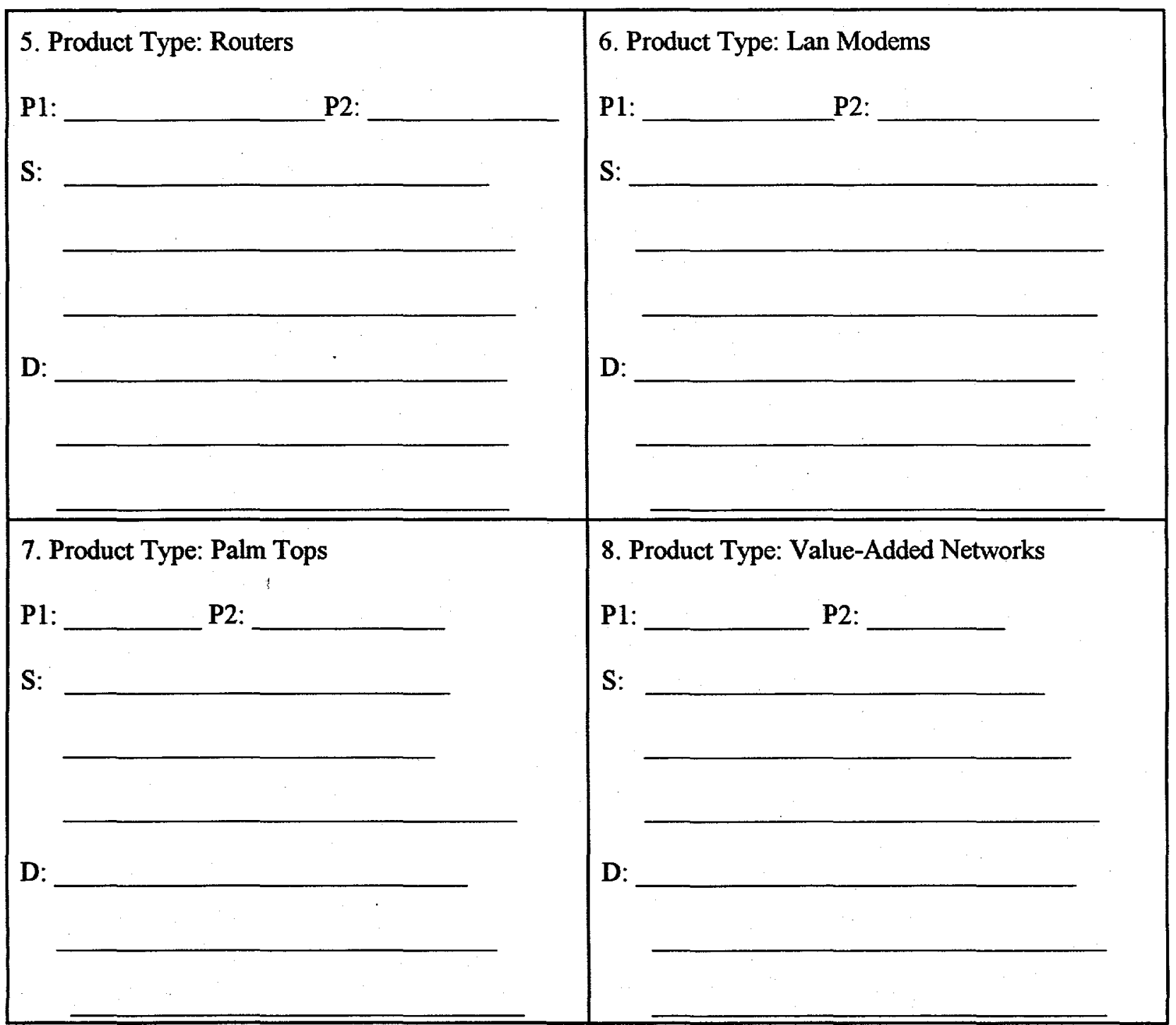

A -37 


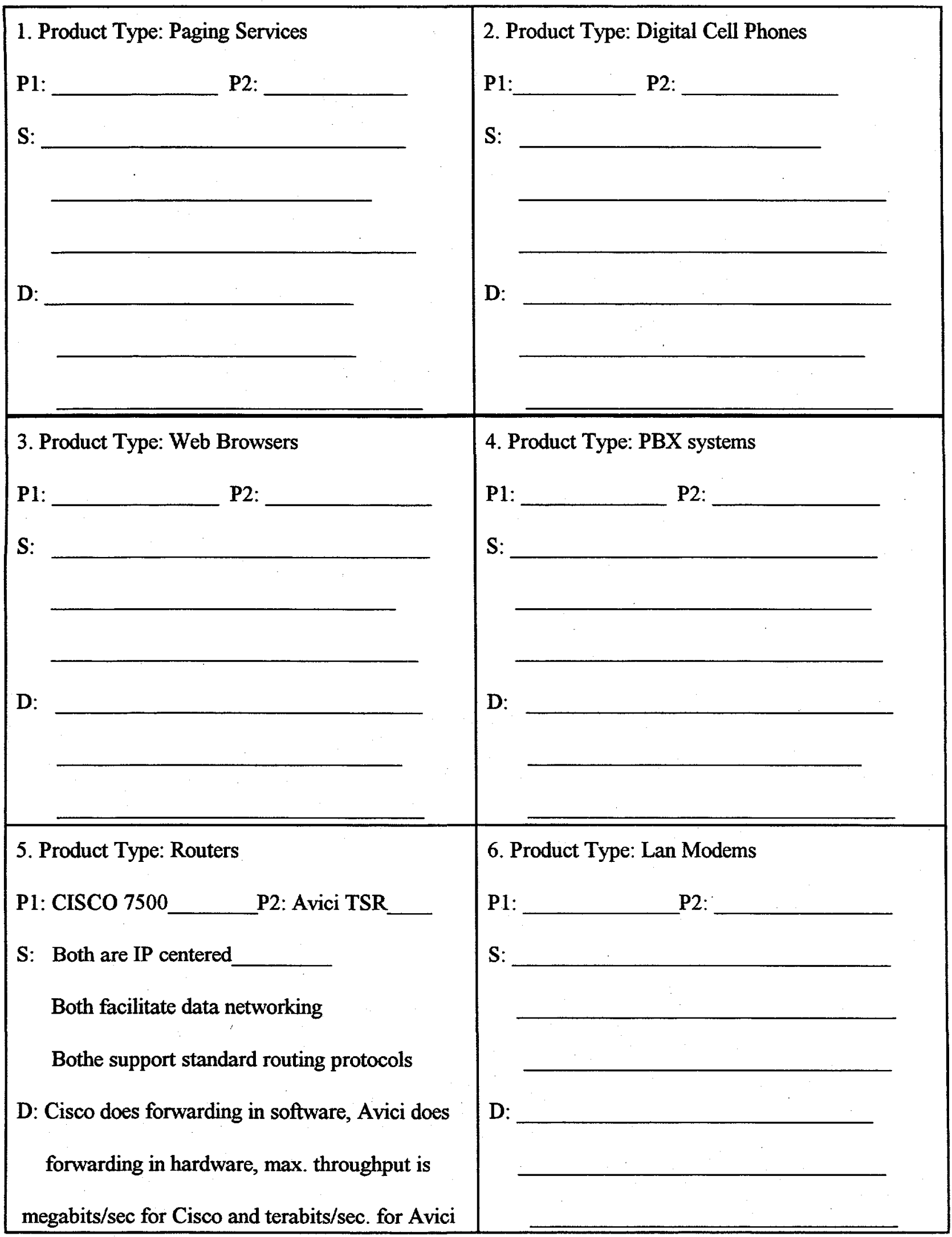

$$
\text { A - } 38
$$




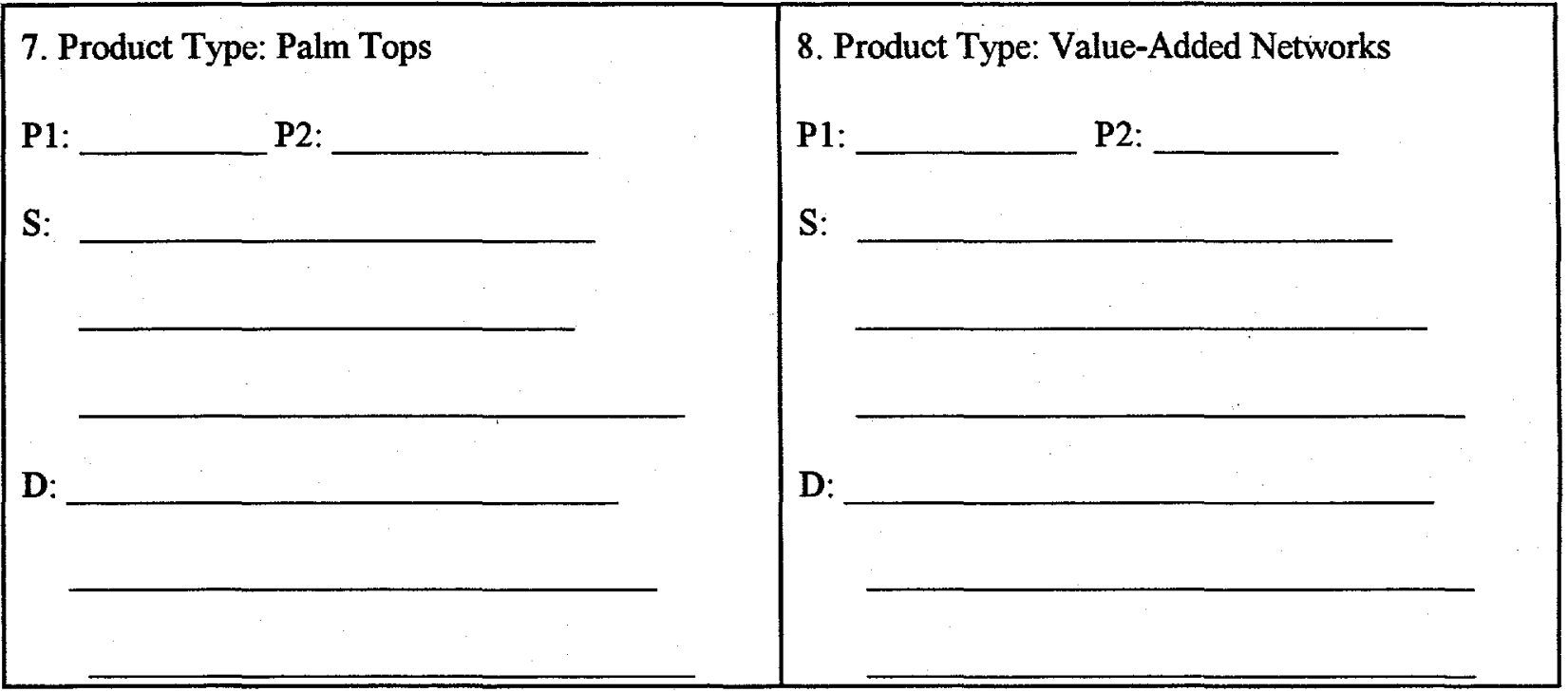

\begin{tabular}{|l|l|}
\hline 1. Product Type: Paging Services & 2. Product Type: Digital Cell Phones \\
P1: Palm Pilot (3Com)P2: Bravo (Motorola) & $\mathrm{P1:}$ \\
S: Alpha numeric paging & $\mathrm{S}:$ \\
$\quad$ Two-way pagingfunctions & \\
\hline D: P1 combines telephone lists and storage & $\mathrm{D}:$ \\
\hline P1 synchronizes telephone books with PC & \\
\hline
\end{tabular}

A - 39 
3. Product Type: Web Browsers

P1: Netscape

P2: IE (Microsoft)

S: http browser

store favorite sites

D: P2 takes up significant disk space

$\mathrm{P1}$ is a more intuitive interface

5. Product Type: Routers

P1: 3COM Netbuilder P2: Cisco 2501

S: packet forwarding

LAN + WAN interface options

D: $\mathbf{P} 2$ is complex to configure

P2 software + cable options are to complex

P2 is intimidating to order or configure

7. Product Type: Palm Tops

P1: Palm Pilot 3Com P2: Casio

S: Compact storage/entry of user data

light weight, hand writing input

D: P1 fits in shirt pocket

Pl integrates e-mail and pager
4. Product Type: PBX systems

P1: P2:

S:

D:

6. Product Type: Lan Modems

P1: Ascend Pipeline P2: 3Com OC DA

S: Economical internet or large net connection small LAN to internet

D: P1 has difficult command

P2 has graphical interface

8. Product Type: Value-Added Networks

P1: UUNet Extralink P2: Compuserve

S: Site-to-site connectivity

D:

$$
\text { A }-40
$$




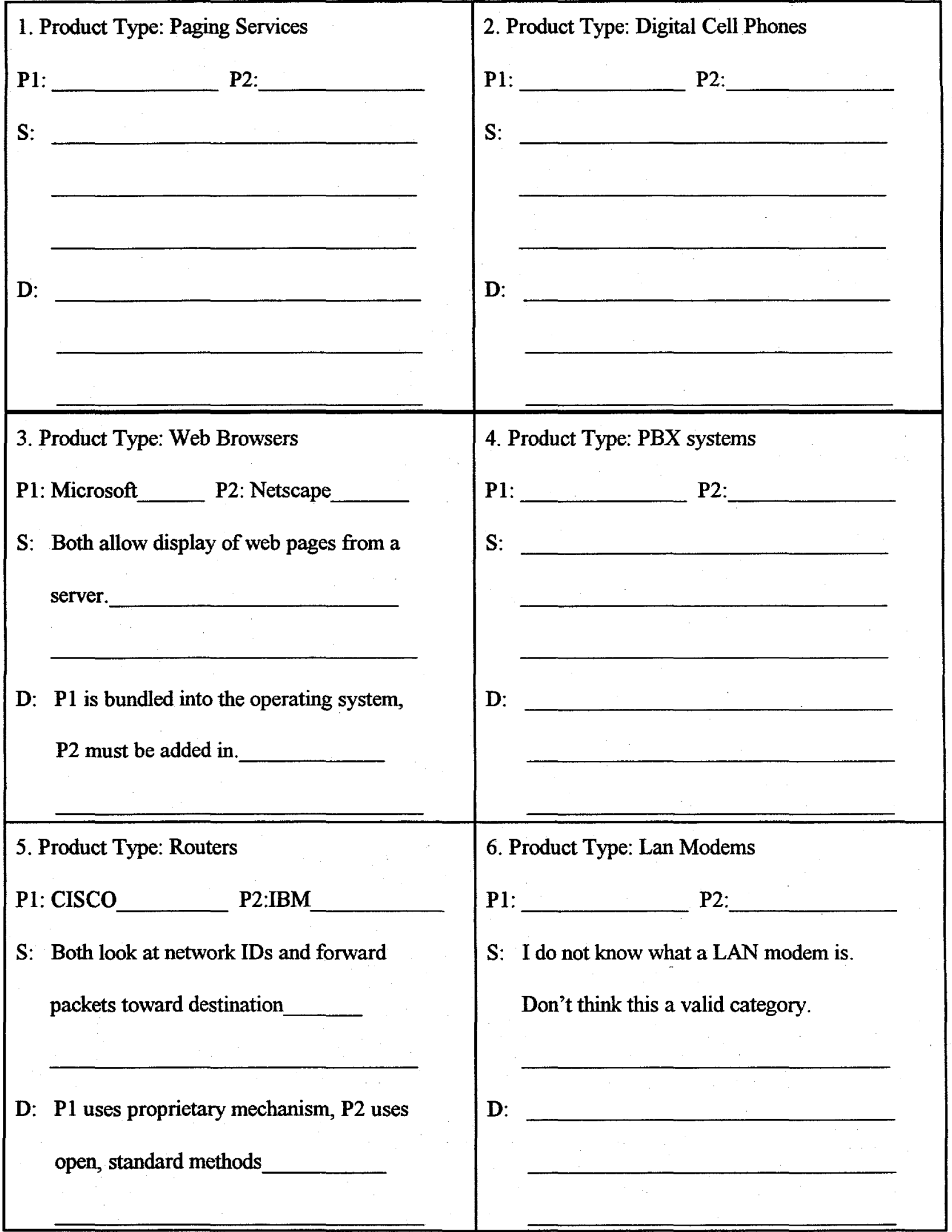


7. Product Type: Palm Tops

P1: 3M/USRobotics

P2: SEICO

S: Manage calendars and contacts

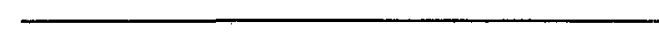

D: P1 has much more power

1. Product Type: Paging Services

P1: Pagenet

P2: Skytel

$S:$ Don't know details of paging

D:
8. Product Type: Value-Added Networks

P1: IBM Global P2:AT\&T

S: Both allow private transactions over a public network

D: P1 has much greater worldwide presence

2. Product Type: Digital Cell Phones

P1: P2:

S:

D: 
3. Product Type: Web Browsers

P1: Navigator

P2: IIE

S: similar look

similar response times

D: more value add for Navigator

5. Product Type: Routers

P1: CISCO

P2: Bay

S: OJPF

Reports

D: IGRP

Network management

7. Product Type: Palm Tops

P1:

P2:

S:

D:

:
4. Product Type: PBX systems

P1: Lucent ??? P2: Nortel Meridian

S: similar features

D: voice mail flow

6. Product Type: Lan Modems

P1: USRobitcs P2: Gobal Village

S: similar look and feel

Ease of use

D: different modulation

Apple vs. Intel

8. Product Type: Value-Added Networks

P1: P2:

S:

D: 


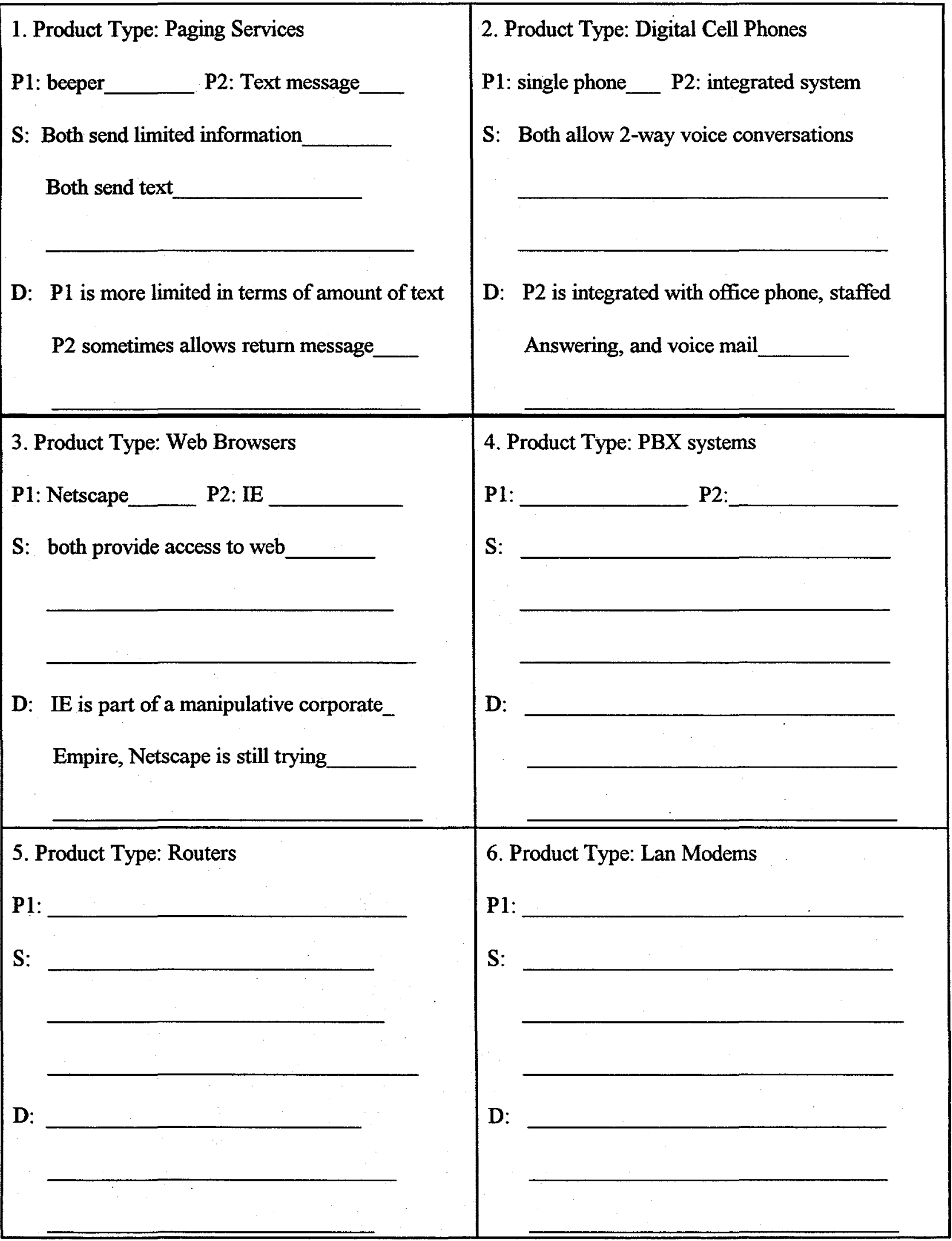

A - 44 
7. Product Type: Palm Tops

P1: Palm Pilot

P2: Newton

S: Both are portable

light weight, hand writing input

D: Newton is being discontinued

1. Product Type: Paging Services

P2:

P1:

S:

D:

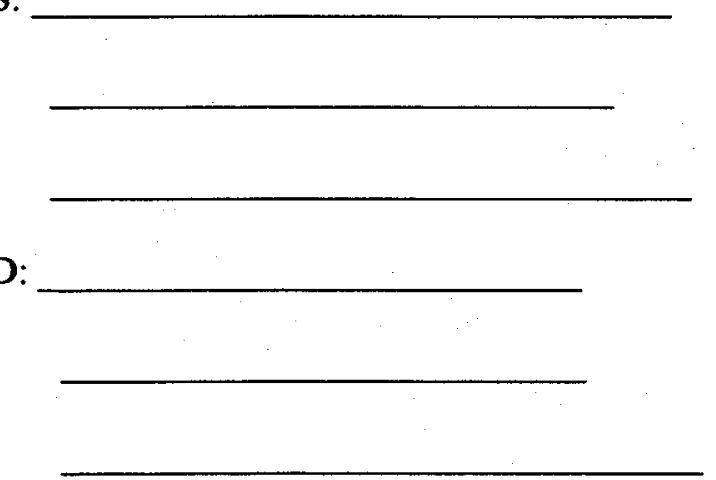

8. Product Type: Value-Added Networks

P1: P2:

S:

D:

2. Product Type: Digital Cell Phones

P1:

P2:

S:

D: 


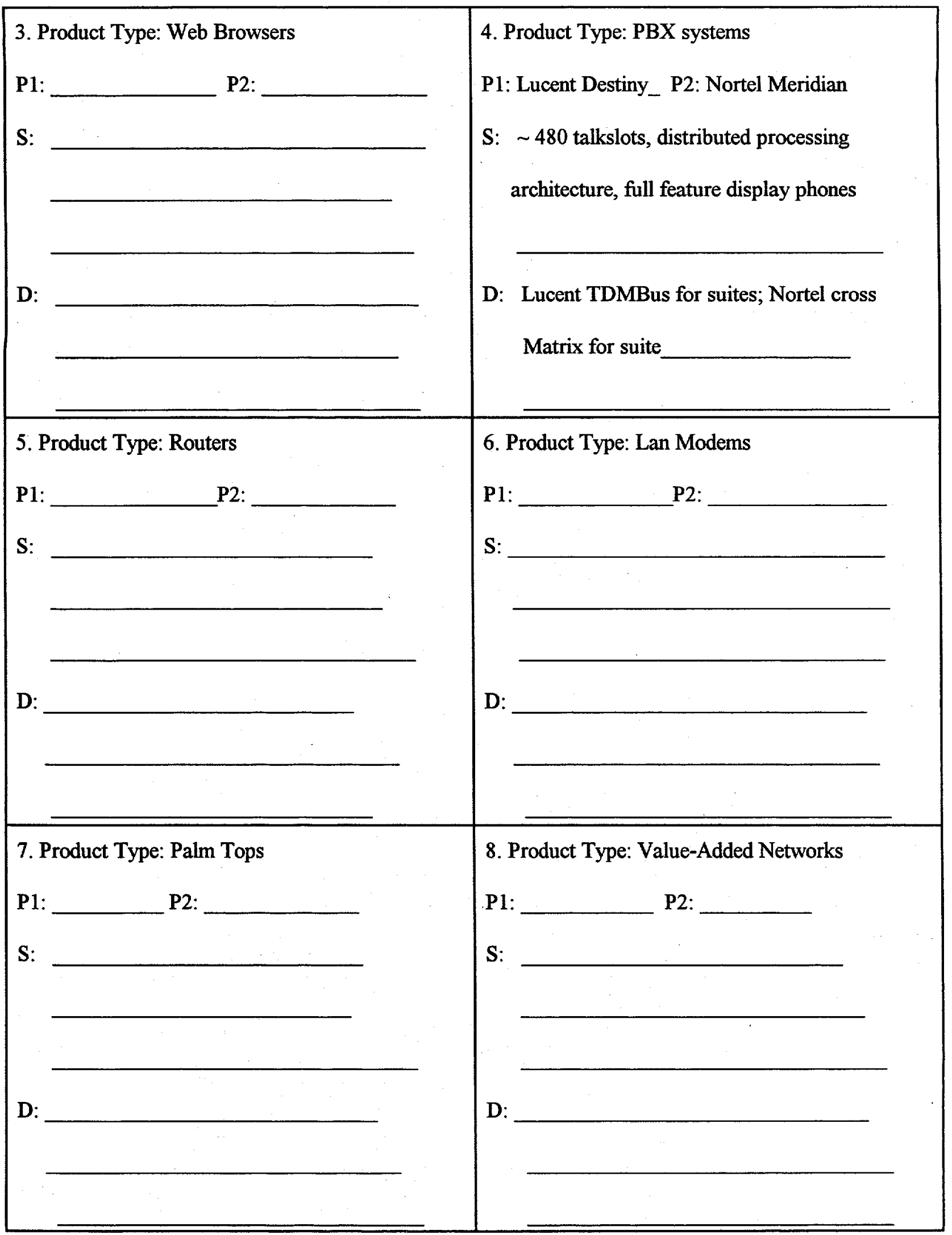

A -46 


\section{APPENDIX G: DRAFT PRODUCT DESCRIPTIONS}

\section{Product Type: Paging Services}

Example Products: Palm Pilot (3Com), Bravo (Motorola)

\section{COMMUNICATIONS CAPABILITIES}

1. One-way paging functions

2. Two-way paging functions

\section{TYPES OF DATA COMMUNICATED}

1. Alpha numeric paging

\section{PAGING SERVICES}

1. Beeper only

2. Beeper and limited text messages

3. Beeper and extensive text messages

\section{COMPLEMENTARY FEATURES}

1. Combines telephone lists and storage

2. Synchronizes telephone books with PC

\section{Product Type: Digital Cell Phones}

Example Products: Sprint PCS, AT\&T Cellular

\section{TYPE OF COMMUNICATION}

1. Analogue

2. Digital

\section{SCOPE OF SERVICE}

1. Limited coverage

2. National coverage

\section{PRODUCT DESIGN}

1. Small size

2. Larger size

COMMUNICATION STANDARDS

1. Different digital standards

2. Sprint usable

\section{COMPLEMENTARY FEATURES}

1. Single phone

2. Integrated office system

3. Integrated with answering and voice mail services

3. Product Type: Web Browsers 
Example Products: Navigator (Netscape), Internet Explorer (Microsoft)

\section{ACCESSIBILITY OF SOFTWARE TO USERS}

1. Bundled into the operating system

2. Must be added in

USER FRIENDLINESS

1. User friendly interface

2. Experience needed to use product

\section{FUNCTIONALITY}

1. Extensive functionality

2. Added value

\section{TECHNICAL QUALITY}

1. Response time

2. Disk space requirements

\section{PRODUCT SUPPORT}

1. Large company product

2. Small company product

\section{Product Type: PBX systems}

Example Products: Lucent Destiny, Nortel Meridian

\section{TECHNICAL FEATURES}

1. $\sim 480$ talkslots

2. Distributed processing architecture

3. Full feature display phones

4. Voice mail flow

\section{TECHNICAL APPROACH}

1. TDMBus for suites

2. Cross matrix for suites 


\section{Product Type: Routers}

Example Products: CISCO 7500, Cisco 2501, Avici TSR, 3COM Netbuilder, Bay, IBM

\section{PACKET FORWARDING APPROACH}

1. Forwarding in software

2. Forwarding in hardware

\section{DATA TRANSFER SPEEDS}

1. Megabits/sec

2. Terabits/sec

\section{PRODUCT COMPLEXITY}

1. Straightforward to configure

2. Complex to configure

3. Intimidating to order

4. Software + cable options are to complex

\section{INTEROPERABILITY}

1. Uses open standards and methods

2. Uses proprietary mechanisms

\section{OTHER FEATURES}

1. IP centered

2. Facilitates data networking

3. Support standard routing protocols

4. LAN + WAN interface options

5. OJPF

6. IGRP

7. Network management

8. Reports

\section{Product Type: Lan Modems}

Example Products: Ascend Pipeline, 3Com OC DA, USRobotics, Global Village

\section{CONNECTIVITY}

1. Large net connection

2. Small LAN to internet

3. Economical internet

\section{EASE OF USE}

1. Difficult command language

2. Graphical interface

3. Look and feel

TECHNICAL FEATURES

1. Modulation approach 
7. Product Type: Palm Tops

Example Products: Palm Pilot 3Com, Casio, 3M/USRobotics, SEICO

PRODUCT DESIGN

1. Fits in shirt pocket

2. Light weight

DATA ENTRY FEATURES

1. Compact storage/entry of user data

2. Hand writing input

\section{COMPLEMENTARY FEATURES}

1. Integrates e-mail and pager

2. Manage calendars and contacts

\section{PROCESSING CAPABILITIES}

1. Has much more power

\section{Product Type: Value-Added Networks}

Example Products: UUNet Extralink, Compuserve , IBM Global, AT\&T

TECHNICAL FEATURES

1. Site-to-site connectivity

2. Allows private transactions over a public network

\section{SCOPE OF SERVICE}

1. Worldwide presence 


\section{INTERNAL DISTRIBUTION}

1. J. B. Cannon

2. S. Carnes

3. G. E. Courville

4. T. R. Curlee

5. S. G. Hildebrand

6. R. Lee

7. C. I. Moser
8. R. B. Shelton

9. B. E. Tonn

10. Central Research Library

11. Document Reference Section

12. Laboratory Records

13. Laboratory Records - RC

\section{EXTERNAL DISTRIBUTION}

14. Dr. Lilia A. Abron, President, PEER Consultants, P.C., 1460 Gulf Blvd., $11^{\text {th }}$ Floor, Clearwater, FL 34630 .

15. Fred Conrad, Bureau of Labor Statistics, Room 4930, Two Massachusetts Avenue, NE, Washington, DC 20212.

16. Dr. Susan L. Cutter, Department of Geography, University of South Carolina, Columbia, SC 29208.

17. Mr. P. Richard Rittelmann, FAIA, Executive Vice President, Burt Hill Kosar Rittelmann Associates, 400 Morgan Center, Butler, PA 16001-5977.

18. Dr. Susan F. Tierney, The Economic Resource Group, Inc., One Mifflin Place, Cambridge, MA 02138.

19. Dr. C. Michael Walton, Department of Civil Engineering, College of Engineering, The University of Texas at Austin, Cockrell Hall, Suite 4.2, Austin, TX 78712.

20. Office of Scientific and Technical Information, U.S. Department of Energy, P.O. Box 62, Oak Ridge, TN 37831. 